Archived version from NCDOCKS Institutional Repository http://libres.uncg.edu/ir/asu/

\title{
Appalachỉan
}

B O O N E, N O R T H C A R O L I N A

\section{Financial Disclosure Management In The Nonprofit Sector: A Framework For Past And Future Research}

\author{
By: Mary Ann Hofmann and Dwayne McSwain
}

\begin{abstract}
This paper provides a review and synthesis of past research regarding financial disclosure management by nongovernmental nonprofit organizations and suggests directions for future study. The primary purpose of this review is to summarize the evidence on financial disclosure management to help regulators and other stakeholders understand why, how, and to what extent nonprofits engage in this behavior. The paper begins by defining disclosure management in nonprofit organizations and exploring the motivations for why it might occur. Next is a survey of the nongovernmental nonprofit financial reporting environment: objectives, common practices, and the informational needs of users of nonprofit financial reports. Research exploring the motives, methods, and consequences of disclosure management is summarized. The evidence suggests that nongovernmental nonprofit managers have a variety of incentives to manage reported numbers and that they do in fact alter spending decisions, choose accounting methods, and design cost allocations to achieve certain performance benchmarks. Furthermore, this review sheds light on the consequences of disclosure management and what can or should be done to limit it.
\end{abstract}

Hofmann, Mary Ann \& McSwain, Dwayne, 2013. "Financial disclosure management in the nonprofit sector: A framework for past and future research," Journal of Accounting Literature, Elsevier, vol. 32(1), pages 61-87. DOI: 10.1016/i.acclit.2013.10.003. Publisher version of record available at: https://www.sciencedirect.com/ science/article/pii/S0737460713000207 


\title{
Financial disclosure management in the nonprofit sector: A framework for past and future research
}

\author{
Mary Ann Hofmann *, Dwayne McSwain
}

Appalachian State University, United States

\section{A B S T R A C T}

\section{Keywords:}

Earnings management

Disclosure management

Nonprofit accounting
This paper provides a review and synthesis of past research regarding financial disclosure management by nongovernmental nonprofit organizations and suggests directions for future study. The primary purpose of this review is to summarize the evidence on financial disclosure management to help regulators and other stakeholders understand why, how, and to what extent nonprofits engage in this behavior. The paper begins by defining disclosure management in nonprofit organizations and exploring the motivations for why it might occur. Next is a survey of the nongovernmental nonprofit financial reporting environment: objectives, common practices, and the informational needs of users of nonprofit financial reports. Research exploring the motives, methods, and consequences of disclosure management is summarized. The evidence suggests that nongovernmental nonprofit managers have a variety of incentives to manage reported numbers and that they do in fact alter spending decisions, choose accounting methods, and design cost allocations to achieve certain performance benchmarks. Furthermore, this review sheds light on the consequences of disclosure management and what can or should be done to limit it.

* Corresponding author.

E-mail address: hofmannma@appstate.edu (M.A. Hofmann). 


\section{Introduction}

In this paper we review the scholarly research on financial disclosure management in the nonprofit sector. ${ }^{1}$ Recent financial scandals involving public charities, such as the National Capital Area United Way and the Red Cross, have shaken the public's confidence in public charities and have resulted in serious decreases in donations to those organizations (Dimsdale, 2009; Rucker, 2007). These scandals have also shed light on the unique financial reporting environment of nonprofit entities and how it creates incentives and opportunities for financial disclosure management, which in turn can lead to a misallocation of charitable donations and a failure to optimize philanthropic output. The primary purpose of this review is to summarize the evidence on financial disclosure management to help regulators and other stakeholders understand why, how, and to what extent nonprofits engage in this behavior. Furthermore, the review sheds light on the consequences of disclosure management and what can or should be done to limit it.

There is a large stream of research examining earnings management in the for-profit sector, where managers use judgment in financial reporting and in structuring transactions to alter financial reports either to mislead some stakeholders about the underlying economic performance of the company or to influence contractual outcomes that depend on reported accounting numbers (Healy \& Wahlen, 1999). However, nonprofit entities differ from profit entities in ways that can affect reporting incentives and constraints. The objective of nonprofit management is not the maximization of shareholder wealth as it is for the typical profit-seeking firm. Nonprofits serve a different set of stakeholders and measure economic performance somewhat differently. Nonetheless, research shows that nonprofits, like for-profit firms, have both motives and opportunities to misreport financial information in order to mislead stakeholders or influence contractual outcomes. Since nonprofit organizations do not focus on earnings or profits as such, we use the more general term "financial disclosure management" or simply "disclosure management" rather than "earnings management" to describe the opportunistic use of financial reporting and real-transaction management to affect stakeholders' perceptions of firm performance.

The nonprofit sector is an important and rapidly growing part of the United States economy. In 2008, the most recent year for which there is data, nonprofits that report to the Internal Revenue Service (IRS) accounted for approximately \$1.9 trillion in revenue and \$4.3 trillion in assets (Wing, Roeger, \& Pollak, 2010). ${ }^{2}$ Nonprofits enrich our lives through art and culture and provide many goods and services that the government might otherwise be called upon to fund. Charitable giving can be thought of as a form of voluntary wealth redistribution and is considered very much part of the American way of life. Most estimates place the percentage of American households that make monetary contributions each year at 70-80 percent, and the average American household contributes more than $\$ 1000$ annually (Brooks, 2008). If nonprofit organizations manage their financial disclosures to mislead stakeholders, then allocation of resources to and within this sector of the economy may be suboptimal.

The remainder of the paper proceeds as follows. Section 2 discusses the theoretical underpinnings for the study of financial disclosure management: information asymmetry, the agency problem, and the nonprofit objective function. The nonprofit financial reporting environment and the role of charity watchdog groups as financial information intermediaries are discussed next, to show how the unique characteristics of the nonprofit environment create

\footnotetext{
${ }^{1}$ Accounting research on nonprofit entities focuses on either governmental or nongovernmental units.

Our review is limited in scope to nongovernmental units. While federal, state and local governments and their agencies are broadly considered to be part of the nonprofit sector, the financial, regulatory and reporting environments in which they operate set them apart as a separate field of research. In particular, governments and their agencies are created by a political process, are often funded by tax money (and often have the ability to increase revenues by raising taxes), do not typically conduct fundraising, seldom receive donations, and are subject to different forms of governance, regulation, and reporting requirements. They do not request tax exemption from the IRS, and they do not report to the IRS via Form 990.

${ }^{2}$ These numerical facts do not include small nonprofits with gross receipts less than $\$ 25,000$ or religious congregations, which are exempt from reporting requirements.
} 
unique motives and opportunities for financial disclosure management. Section 3 discusses the building blocks of disclosure management research: data sources and statistical and econometric methodologies. Sections 4-6 review the findings of studies that test for and analyze misreporting or disclosure management. ${ }^{3}$ Section 4 reviews research related to donationsmarket and contracting motivations for disclosure management, while Section 5 reviews research related to regulatory motivations-disclosure management to minimize political costs and taxes. ${ }^{4}$ Section 6 discusses what research has shown to be the consequences of financial disclosure management in the nonprofit sector as well as what can be done to mitigate the problem. Finally, Section 7 summarizes the state of the research to date and suggests avenues for future study.

\section{Theoretical underpinnings}

\subsection{Information asymmetry, agency costs, and the nonprofit objective function}

The primary roles for accounting information, valuation, and stewardship (Beyer, Cohen, Lys, \& Walther, 2010) are as applicable in the nonprofit sector as in the for-profit sector. Potential donors want to know that nonprofits will be able to use their contributions in meaningful, effective, and efficient ways, and creditors want to be able to assess credit risk and return (Parsons, 2003). Managers likely possess more information about the organizations' financial condition and mission-related program service opportunities than outsiders. This information asymmetry creates a demand for financial reporting and an opportunity for financial disclosure management. Information asymmetry is greater in nonprofits than in corporations because there are, in effect, two principals: the donor and the beneficiary of the nonprofit's goods and services (Kitching, 2009). The donor may provide capital, but other parties are the beneficiaries of the net earnings from that capital. To look at it another way, the donor purchases a benefit such as humanitarian aid, while third-party beneficiaries actually receive the product or service paid for. In many cases, the donor has limited knowledge of the needs or preferences of the beneficiary. Information asymmetry in the nonprofit sector is exacerbated by the fact that not all stakeholders have access to the same quantity or quality of financial information, as discussed in Section 2.2.

Donors and creditors experience agency problems with managers of nonprofits similar to those faced by stockholders of public corporations, because resource providers do not have full decisionmaking rights, and because management does not fully bear the financial risk or the wealth effects of its decisions (Core, Guay, \& Verdi, 2006; Fama \& Jensen, 1983a). In the nonprofit world, this agency problem is usually dealt with by utilizing a self-perpetuating board of trustees (Fama \& Jensen, 1983b), whose primary purpose is to direct executive activities on behalf of the stakeholders (Aggarwal, Evans, \& Nanda, 2012). The board of trustees uses accounting information (among other types of information) to monitor the stewardship of management. Implicit and explicit contracts with creditors, managers, and other resource providers also incorporate accounting information. Because of the potential for nonprofits to abuse their tax-exempt status or to channel donated funds to the benefit of insiders, federal and state regulatory agencies demand accounting information from nonprofit organizations (Desai \& Yetman, 2005). Thus, information asymmetry, agency problems, contracting, governance, and regulation all create demand for ex-post accounting information and provide motives and opportunities for financial disclosure management.

There is a substantial body of literature dealing with the motives for and the methods of earnings management by publicly traded corporations, but due to differences in the way nonprofits are financed and governed, one cannot assume that those motivations or methods would be applicable to

\footnotetext{
${ }^{3}$ The papers included in this review cover a time period of about 25 years. However, due to the many changes in reporting standards and data availability in the recent past, the focus is primarily on the more recent studies as they are likely to be the most relevant going forward.

${ }^{4}$ Political costs refer to the costs of additional regulation, including higher taxes, borne by large or high-profile firms (Watts and Zimmerman, 1986). Nonprofits are exempt from tax on their program-related activities but are taxed on business activities that are unrelated to their mission. Private non-operating foundations are also subject to taxes on undistributed income.
} 
the nonprofit sector. ${ }^{5}$ Fama and Jensen (1983b) posit that the nonprofit form of organization dominates endeavors that are funded by donations because the absence of residual equity holders assures donors that contributed funds will not be diverted to such claimants. ${ }^{6}$ The important feature of the nonprofit form of organization is not that nonprofits cannot or do not make a profit but that there are no alienable claims to profits (or to net assets). A corollary to that observation is that since donors do not require a financial return on investment, the organization can provide the desired goods or services at a lower cost.

Further, the distinction between for-profit and nonprofit organizations goes beyond the absence of residual claims to the very nature of relationships between inputs and outputs. Profit-seeking firms use capital from equity holders and creditors to provide the factors of production and incur expenses to produce a product or service that is sold to customers. As a general rule, expenses are incurred for the purpose of increasing revenues or profits. In the nonprofit organization, the distinction between revenue and contributed capital is not so clear, and the linkage between expenses and revenues can differ. Nonprofits, or at least those financed primarily by donations, receive resources from donors to provide goods and services to beneficiaries. Rather than incurring expenses to generate revenues, many charitable nonprofits receive revenues (although they may incur some fundraising expenses to do so) to incur program service expenses. Profit maximization is irrelevant. In fact, several researchers suggest there are political costs associated with showing a profit: a surplus of revenues over expenses implies that the nonprofit is not fulfilling its charitable mission (Jones \& Roberts, 2006; Leone \& Van Horn, 2005).

So what is the goal of the nonprofit firm? Steinberg (1986) posits that nonprofits at one extreme seek to maximize gross resources (revenues) and at the opposite extreme seek to maximize the residual available for charitable service (which implies simultaneous maximization of revenues and program service expenditures and minimization of fundraising and administrative expenses). He refers to the first group as budget maximizers and the second as service maximizers. Most of the research to date relating to financial disclosure management in the nonprofit sector seems to assume the latter objective is the prevalent one or at least the one that donors would endorse, but results from empirical tests of objective functions are mixed. ${ }^{7}$ Jegers (2010) defines the agency problem existing between the board of trustees and nonprofit management as the disparity between objective functions; the board's goal is service maximization, while the manager's goal is budget maximization. If the objective is to maximize revenues, then managers will have incentives to manage financial disclosures in such a way as to encourage more donations. If the objective is to maximize funds expended on program services, then management may wish to disclose information that makes it appear that they have been successful in doing so, especially if their compensation is tied in any way to donations or program spending.

\footnotetext{
${ }^{5}$ The studies cited in this note are simply examples drawn from a large body of literature. Healy and Wahlen (1999) and Stolowy and Breton (2004) provide comprehensive reviews of earnings management research. Studies have documented evidence that corporations manage earnings to reduce political or regulatory costs or increase regulatory benefits (e.g., Han and Wang, 1998), to increase earnings-based compensation (e.g., Guidry, Leone, \& Rock, 1999), to avoid violation of debt covenants (e.g., DeFond and Jiambalvo, 1994), to meet analysts' forecasts (e.g., Kasznik, 1999), to avoid small losses or earnings decreases (e.g., Burgstahler and Dichev, 1997), to inflate earnings prior to equity offerings (e.g., Teoh, Welch, \& Wong, 1998), or to minimize taxes (Lopez, Regier, \& Lee, 1998). Researchers have also examined a variety of methods firms use to accomplish earnings management, including management of accruals such as allowance for bad debts, deferred, and other valuation accounts or reserves (e.g., Beaver, McNichols, \& Nelson, 2003; Phillips, Pincus, Rego, \& Wan, 2004); and the manipulation of real activities such as price discounts, overproduction, and reduction of discretionary expenditures (Roychowdhury, 2006) and even the strategic timing of charitable contributions to corporate foundations (Petrovits, 2006).

${ }^{6}$ To qualify for federal tax-exemption, IRC Section 501(c) requires that no part of the net earnings of a nonprofit organization may inure to the benefit of any shareholder or any individual having a personal and/or private interest in the activities of the organization.

${ }^{7}$ Steinberg (1986) finds that healthcare nonprofits in his sample are budget maximizers, while welfare, education, and arts firms are service maximizers. Weisbrod and Dominguez (1986) estimate the fundraising elasticity of donations for a sample of nonprofits filing Form 990 tax returns for the four years 1973-1976 and find that it is not significantly different from zero in all seven industry segments considered. They conclude from this that "nonprofit firms are not maximizers of net expenditures on output" (service maximizers); however, "they may be maximizers of total expenditures" (budget maximizers). In contrast, Posnett and Sandler (1989) find that their sample of U.K. charities "maximize the surplus available for expenditure on charitable output," which makes them service maximizers.
} 


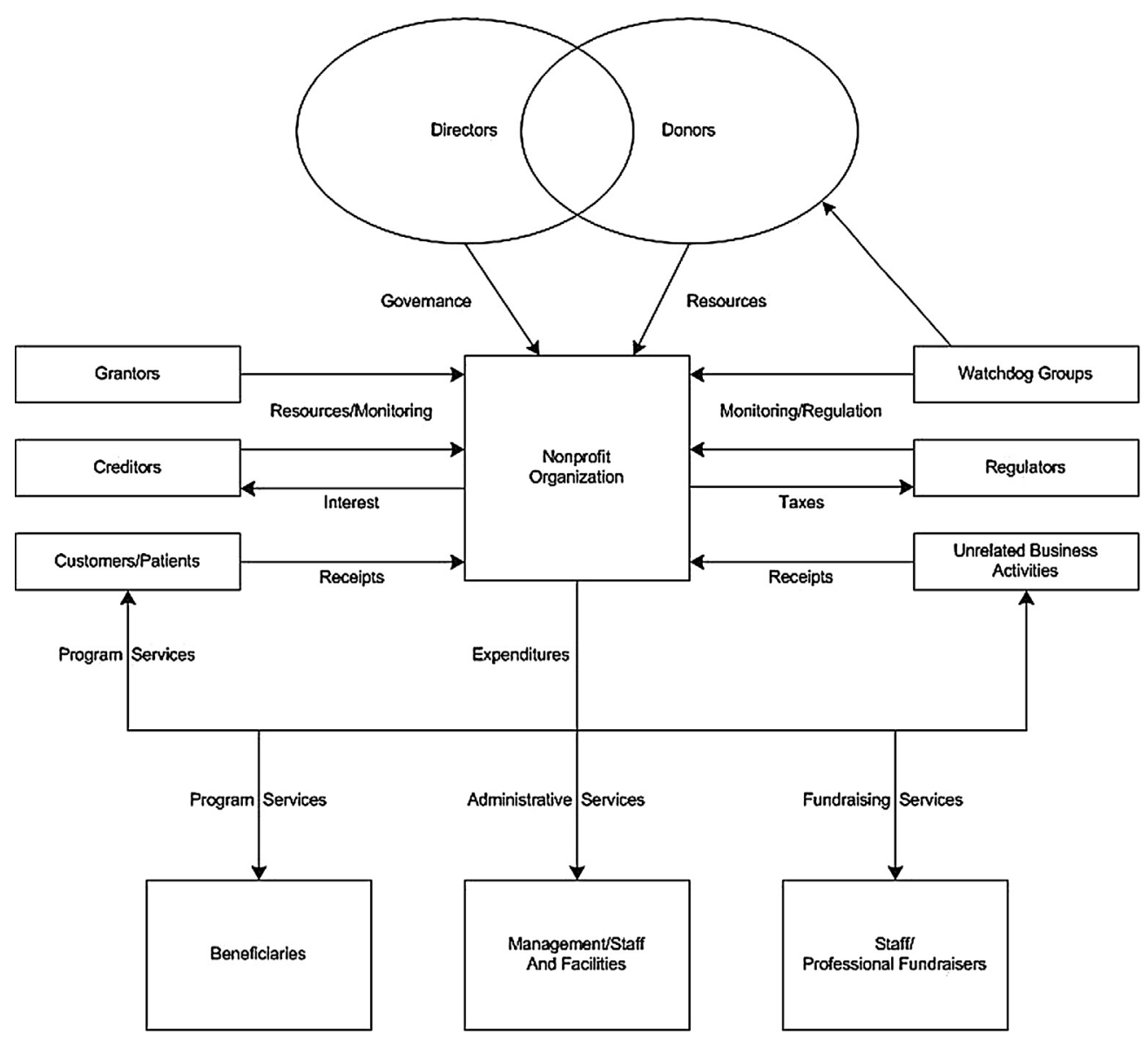

Fig. 1. Nonprofit stakeholders.

Fig. 1 summarizes the relationship between the nonprofit organization and its various stakeholders.

\subsection{The nonprofit financial reporting environment}

Standards for financial reporting by nongovernmental, nonprofit entities are set by the Financial Accounting Standards Board (FASB). In 1993, the FASB revised its standards for nonprofits in an effort to enhance the usefulness of the disclosures and to provide greater uniformity in financial reporting. Statement of Financial Accounting Standards No. 117 requires three financial statements: the Statement of Financial Position (a balance sheet), the Statement of Activities (a statement of revenues and expenses), and a Statement of Cash Flows (FASB, 1993). Expenses are reported by function and classified as either program services or supporting services on the Statement of Activities. Additionally, voluntary health and welfare organizations (VHWO) must prepare a Statement of Functional Expenses, which presents expenses by object class, or type of expense, within the program services and supporting services categories. These statements are designed to help resource providers make assessments concerning how well the nonprofit performed, how well it can continue to provide services, and how well management has discharged its stewardship (Khumawala \& Gordon, 1997).

Surprisingly, there is no mechanism to ensure that the audited financial statements of nonprofit organizations are made available to potential users. Nonprofit organizations are not legally required to 
provide such statements to anyone but certain government agencies. ${ }^{8}$ Unlike publicly traded corporations, nonprofit corporations are not regulated by the Securities and Exchange Commission, but rather by the IRS (Simon, Dale, \& Chisolm, 2007). A nonprofit must obtain tax exemption from the IRS by filing a registration statement. If a nonprofit organization qualifies for exemption under Internal Revenue Code (IRC) Section 501(c)(3), then it is also authorized to receive tax-deductible contributions. Most nonprofits are subject to annual filing of IRS Form 990, an informational tax return, and charitable nonprofits must complete a Statement of Functional Expenses. ${ }^{9}$ The IRS Form 990 also includes schedules for reconciling total revenues and expenses shown on the tax return with amounts shown on audited financial statements, for disclosing compensation paid to officers and directors, and for analyzing the organization's sources of revenue. Form 990 tax returns have been subject to public disclosure since 1996, and in recent years the disclosure requirements have expanded.

Thus, for charitable nonprofits, the principal, regulated annual disclosure of financial information is IRS Form 990, not audited financial statements (Keating \& Frumkin, 2003). The quantity and quality of information provided on Form 990 (available to outsiders) may not be the same as that provided on the audited financial statements (often available only to insiders, the Board of Trustees, and some state regulatory agencies) (Kitching, 2009). The fact that different user groups have access to different financial reports exacerbates the difficulty of researching financial-disclosure management. Should researchers be more concerned with the numbers reported on Form 990 or the audited financial statements? Does evidence of disclosure management based on analysis of IRS Form 990 filings imply that the audited financial statements are also biased? Comparisons of disclosures found on the IRS Form 990 with those made in audited financial statements (Krishnan, Yetman, \& Yetman, 2006) or in annual reports to state regulatory agencies (Keating, Parsons, \& Roberts, 2008; Krishnan \& Yetman, 2011) reveal significant differences in the amounts of program service, administrative, or fundraising expenses reported.

While institutional donors and large individual donors may request a copy of a nonprofit's Form 990 or audited financial statements, the average individual donor may not know what information is available, how to obtain the information, or how to read and interpret financial statements (Keating \& Frumkin, 2003). Several independent agencies have emerged in the recent past to act as information intermediaries for the charitable nonprofit sector. GuideStar, the Council of Better Business Bureaus' Wise Giving Alliance (CBBB), and Charity Navigator, for example, maintain websites where the public can access financial information about nonprofits, including copies of recent Forms 990. These organizations also publish standards and rate nonprofits on a number of measures of organizational efficiency and capacity. CBBB standards require, for example, that charities devote at least 65 percent of annual expenses to program activities. Charity Navigator's ratings are based on measures such as percentage of total expenses that are administrative, fundraising costs per $\$ 1$ contributed, growth in revenues and expenses, working capital, and so forth. A recent study finds that contributions are positively associated with these ratings and with changes in these ratings (Gordon, Knock, \& Neely, 2009).

\subsection{Financial performance measurement and motives for disclosure management}

In the Statement of Functional Expenses on IRS Form 990, as in the Statement of Activities required under generally accepted accounting principles (GAAP), all of the expenses of the organization are classified as either program service, administrative, or fundraising. Program services are those activities that relate to the organization's exempt purpose. The ratio of program service expenses to total expenses-referred to as the program service ratio, program spending ratio, or simply as the program ratio-reflects the portion of an exempt organization's expenses that are devoted to fulfilling

\footnotetext{
${ }^{8}$ The Office of Management and Budget (OMB, 2007) requires stringent audits of nonprofits that expend $\$ 500,000$ or more of federal financial assistance in a fiscal year. Twenty-five states require audited financial statements to be filed along with, or in lieu of, a Form 990. See Kitching (2009, p. 512); and Desai and Yetman (2005, pp. 11-12).

${ }^{9}$ Nonprofits with gross receipts less than $\$ 25,000$, as well as churches and other religious organizations, are exempt from the Form 990 reporting requirements.
} 
its exempt mission and is widely used as a measure of efficiency (Barrett, 1999; Smith, 1993). A number of empirical studies have found that donations are positively associated with the program ratio or negatively associated with its inverse, price (Buchheit \& Parsons, 2006; Callen, 1994; Gordon et al., 2009; Okten \& Weisbrod, 2000; Posnett \& Sandler, 1989; Thornton \& Belski, 2010; Tinkelman, 1998, 1999; Weisbrod \& Dominguez, 1986).

Other measures of efficiency identified by researchers include the fundraising ratio used by CBBB (fundraising expenses as a percentage of total donations received), or administrative expenses as a percentage of total expenses (Greenlee \& Brown, 1999). In each case, the higher the proportion of funds used for expenses other than program services, the less efficient the organization is judged to be. Donors appear to be more willing to give to charities that spend a larger proportion of their revenues on activities that further the charities' missions (and a smaller proportion of their revenues on administrative or fundraising activities), and managers behave as if they feel pressure to optimize these ratios. A majority of nonprofit executives believe that outsiders use IRS Form 990 to monitor the organization's efficiency and that it is important to keep administrative costs low to attract and retain funding (Parsons, Pryor, \& Roberts, 2012). Thus, nonprofit managers have incentives to maximize program expenses or minimize fundraising and administrative expenses, thereby encouraging more donations by favorably impressing donors, grant-makers, and ratings agencies.

Contracts with lenders may specify certain debt thresholds or other covenants designed to protect the creditor, and managers may have incentives to misreport related amounts in order to qualify for better credit ratings or obtain credit at a lower cost (Press \& Weintrop, 1990). Models designed to be used by managers, board members, donors, suppliers, and other resource providers to assess the financial vulnerability of nonprofit firms employ financial indicators that use amounts disclosed on IRS Form 990 (Greenlee \& Trussel, 2000; Tuckman \& Chang, 1991). Baber, Daniel, and Roberts (2002) find evidence that nonprofit managers' compensation is positively associated with program spending, suggesting that nonprofit managers may stand to benefit directly from increases in the program ratio. This compounds the incentive for misreporting amounts spent on program services.

The reporting practices of publicly traded for-profit corporations, nonprofit charities, and noncharitable nonprofits, along with potential motivations for financial disclosure management, are summarized for comparison purposes in Table 1.

\section{The building blocks}

\subsection{Sources of data}

Because it is subject to public disclosure (at least since 1996), Form 990 is a ready source of data for research regarding financial reporting by nonprofits. The IRS's Statistics of Income (SOI) division makes digitized data for a stratified sample of Forms 990 and 990-EZ available for download from its website. The sample includes IRC Section 501(c)(3) organizations and Section 501(c)(4)-(9) organizations. Sampling rates range from 1 percent for small-asset classes to 100 percent for large-asset classes. These microdata records contain balance sheet and income statement line items, as well as weights (to estimate the population), for each organization. The IRS Form 990-T, filed by nonprofits with unrelated business income, was not subject to public inspection until passage of the Pension Protection Act of 2006, which mandates that any Form 990-T filed by a 501(c)(3) organization after August 17, 2006, is a public document. The IRS's SOI division is not currently making Form 990-T data available on its website, but individual nonprofit organizations must make copies available to anyone who makes a request. Yetman, Yetman, and Badertscher (2009) compare disclosures on IRS Forms 990 and 990-T and discuss the relative reliability of such disclosures.

The National Center for Charitable Statistics (NCCS), a project of the Center on Nonprofits and Philanthropy (CNP) at the Urban Institute, makes a variety of data available for research purposes. ${ }^{10}$ Much of NCCS's data is received from the IRS after processing, resulting in a time lag of several years.

\footnotetext{
${ }^{10}$ See the "Guide to Using NCCS Data" at http://nccsdataweb.urban.org/kbfiles/468/NCCS-data-guide-2006c.pdf for a description of the types and sources of data available.
} 
Table 1

Comparison of reporting practices and motivations for financial disclosure management.

\begin{tabular}{|c|c|c|c|c|}
\hline Type of entity & Report & $\begin{array}{l}\text { Legally required } \\
\text { distribution }\end{array}$ & $\begin{array}{l}\text { Common voluntary } \\
\text { distribution }\end{array}$ & $\begin{array}{l}\text { Motivation for financial disclosure } \\
\text { management }\end{array}$ \\
\hline \multirow[t]{2}{*}{$\begin{array}{l}\text { Publicly traded } \\
\text { for-profit } \\
\text { corporation }\end{array}$} & $\begin{array}{l}\text { Audited financial } \\
\text { statements (GAAP) }\end{array}$ & $\begin{array}{l}\text { - SEC } \\
\text { - Shareholders } \\
\text { - General public } \\
\text { (on request) }\end{array}$ & $\begin{array}{l}\text { - Stock analysts } \\
\text { - Internet }\end{array}$ & $\begin{array}{l}\text { - Smooth earnings } \\
\text { - Avoid earnings decreases or losses } \\
\text { - Meet analysts' forecasts } \\
\text { - Avoid violating debt covenants } \\
\text { - Maximize managerial compensation }\end{array}$ \\
\hline & Tax return & - IRS & & - Minimize tax liability \\
\hline \multirow[t]{3}{*}{$\begin{array}{l}\text { Nonprofit } \\
\text { charity }\end{array}$} & $\begin{array}{l}\text { Audited financial } \\
\text { statements (GAAP) }\end{array}$ & $\begin{array}{l}\text { - Certain state } \\
\text { departments of } \\
\text { revenue } \\
\text { - Grant-making } \\
\text { agencies }\end{array}$ & $\begin{array}{l}\text { - Major donors } \\
\text { - Charity watch-dog } \\
\text { groups } \\
\text { - Internet }\end{array}$ & $\begin{array}{l}\text { - Protect tax-exempt status } \\
\text { - Meet grant criteria } \\
\text { - Avoid political costs } \\
\text { - Attract donations } \\
\text { - Improve watchdog ratings }\end{array}$ \\
\hline & Tax returns (IRS & • IRS & - Major donors & - Enhance managerial/firm reputation \\
\hline & $\begin{array}{l}\text { Forms } 990,990-\mathrm{T} \text {, } \\
\text { and } 990-\mathrm{PF} \text { ) }\end{array}$ & $\begin{array}{l}\text { - General public } \\
\text { (on request) }\end{array}$ & $\begin{array}{l}\text { - Charity watch-dog } \\
\text { groups } \\
\text { - Internet }\end{array}$ & $\begin{array}{l}\text { - Increase managerial compensation } \\
\text { - Minimize tax on unrelated business } \\
\text { activity } \\
\text { - Minimize taxes on undistributed } \\
\text { income and net investment income } \\
\text { (private non-operating foundations) }\end{array}$ \\
\hline \multirow[t]{3}{*}{$\begin{array}{l}\text { Non-charitable } \\
\text { nonprofit }\end{array}$} & $\begin{array}{l}\text { Audited financial } \\
\text { statements and } \\
\text { IRS Form } 990\end{array}$ & $\begin{array}{l}\text { - Certain state } \\
\text { departments of } \\
\text { revenue }\end{array}$ & $\begin{array}{l}\text { - Members } \\
\text { - Internet }\end{array}$ & $\begin{array}{l}\text { - Enhance managerial reputation } \\
\text { - Increase managerial compensation } \\
\text { - Meet state regulatory standards }\end{array}$ \\
\hline & Tax returns (IRS & - IRS & & - Minimize tax on unrelated business \\
\hline & $\begin{array}{l}\text { Forms } 990,990-\mathrm{T} \text {, } \\
\text { and } 990-\mathrm{PF})\end{array}$ & $\begin{array}{l}\text { - General public } \\
\text { (on request) }\end{array}$ & & activity \\
\hline
\end{tabular}

NCCS's Digitized Dataset, compiled from scanned Forms 990 from 1998 to 2003, contains a number of line items not included in IRS data; the NCCS Core Files begin with 2004 and continue to 2006. GuideStar also receives data from the IRS. In fact, it receives the most recent raw data as soon as they become available. Because GuideStar must process the data itself, it charges a higher fee than does NCCS (Yetman \& Yetman, 2011).

Another federal government source of data is the Office of Management and Budget Federal Audit Clearinghouse (http://harvester.census.gov/sac/), which provides audit information for organizations that receive federal grant money and undergo a "single audit" per OMB Circular A-133 (OMB, 2007). Gordon, Greenlee, and Nitterhouse (1999) discuss nonprofit financial data availability and some of the irregularities and limitations associated with some of the data sources. Some of their discussion may be outdated at this point because of many recent changes. Froelich, Knoepfle, and Pollak (2000) and Fischer, Gordon, and Kraut (2002) compare IRS Form 990 data to audited financial statement data and discuss reliability issues and reporting differences.

Many of the papers included in this review use IRS or NCCS data. Although these data sources are easily accessible and inexpensive, information with enough detail to analyze cost allocations and accruals is generally not available. Some researchers are able to obtain data from federal, state, or industry regulatory agencies or from investment analyst databases. A number of researchers find that state regulatory agencies, such as the State of California's Office of Statewide Health Planning and Development (OSHPD), are richer sources of data that include far more detail, with costs broken down into categories, sometimes even at the departmental level.

\subsection{Statistical and econometric methods}

One of the challenges of studying financial disclosure management is that it can seldom be directly observed. The researcher must infer that numbers are being manipulated or misreported when they 
vary from amounts reported elsewhere or from amounts predicted by a model. Two of the methodologies most commonly employed in the study of earnings management in the for-profit sector that have subsequently been adapted and applied to the nonprofit sector are distributional analyses and discretionary accruals models. A distributional analysis (as in Burgstahler \& Dichev, 1997) examines the distribution of a given accounting measure, such as operating income or return on assets, usually by plotting a histogram. The theory is that absent disclosure management, the distribution around zero, for example, should be smooth. If there is a discontinuity-an unexpectedly small number of firms reporting incomes just below zero, for example, combined with an unexpectedly large number of observations with incomes just above zero-this is taken as evidence of disclosure management.

Discretionary accruals models, sometimes referred to as Jones models, as in Jones (1991) and Dechow and Dichev (2002), attempt to estimate what an appropriate level of (nondiscretionary) accruals should be by regressing a measure of accruals against its lagged value, a measure of the level of activity, and other variables that would influence accruals. Residuals from the estimation model are defined as discretionary accruals, and they are typically used as the dependent variable in further regressions that attempt to find an association between discretionary accruals and managerial incentives for disclosure management. The validity of these techniques in for-profit research has been criticized-there are problems such as sample selection bias, measurement error, and induced correlations, to name a few (Dechow, Richardson, \& Tuna, 2003; Dechow, Ge, \& Schrand, 2010; Durtschi \& Easton, 2005; McNichols, 2000, 2002)-but the basic methodologies have been improved in more recent years to avoid most of those pitfalls. In nonprofit research small sample sizes, data irregularities, and heterogeneous populations may work to lessen the validity of such methods.

The Jones-type model must be adapted for use in nonprofit research, due to differing objective functions and managerial incentives, as discussed in Section 2.1, as well as different accounting methods. Rather than focusing on accruals, nonprofit researchers often attempt to estimate expected program ratios (Baber et al., 2002; Trussel, 2003), levels of charity care (Vansant, 2011), or fundraising or administrative expenses (Yetman \& Yetman, 2011), then use the residuals from these prediction models as their measure of misreporting. The primary difficulty lies in assembling an appropriate cast of independent variables. Trussel (2003), for example, uses a model similar to that used by Baber, Roberts, and Visvanathan (2001) and estimates a normal program ratio by regressing the actual program ratio (program service expenditures divided by total expenses) on size, two fundraising ratios (professional fundraising fees divided by total expenses, total fundraising expenses divided by total contributions) and dummy variables for "industry" (arts, education, human services, etc.) for a large and somewhat diverse group of nonprofits.

There are several weaknesses inherent in these prediction models. First, there may be a certain amount of induced correlation when both the dependent variable and one of the independent variables is scaled by the same measurement, such as total expenses. ${ }^{11}$ Second, most of the variables and their components are interrelated in complicated ways: revenues, contributions, program expenses, total expenses; this may result in a certain amount of endogeneity or simultaneity bias (Greene, 1997, pp. 712-714). Third, it is likely that omitted factors such as managerial dedication; ability to utilize donated supplies, services, and volunteer labor; and ability to identify and pursue program opportunities are more influential on the program ratio than firm size or fundraising, but such variables are impossible to measure and difficult to proxy. As a result, the models can suffer from omitted variable bias or from proxy or measurement error (Greene, 1997, pp. 435-444). Last, the data being used to estimate the expected program ratio is data that has possibly already been managed (later research shows that fundraising amounts, for example, are frequently misreported (Krishnan et al., 2006)), which can also result in measurement error.

It is shortsighted, therefore, to assume that a large prediction error from a Jones-type prediction model is necessarily an indication of disclosure management. Even if the prediction model is well specified, there is always the possibility that unique firm characteristics or unique financial or

\footnotetext{
${ }^{11}$ Several researchers have pointed out that due to the dual impact of fundraising (increasing donations while decreasing the program ratio) it is necessary to include both the program ratio and fundraising expenses in the model to capture both effects. But because the program ratio, administrative ratio, and fundraising ratios sum to unity, statistical problems with multicollinearity can result when more than one such ratio appears in the model.
} 
economic conditions may result in numbers that vary significantly from what the model would predict. Differences in organizational culture could account for wide variations in fundraising, administrative, and program efficiencies that are unrelated to accounting manipulation. Furthermore, firms that engage in disclosure management in order to report program ratios that approach average will go undetected by prediction models based on cross-sectional averages.

Nonprofit researchers have been creative in finding other ways to identify potential disclosure management, including comparisons of audited financial statements or financial reports prepared for a state or industry regulatory agency with Forms 990 submitted to the IRS. Surveys, field studies, simulations, and analytical modeling have also added to our understanding of disclosure management issues. Table 2 summarizes recent financial disclosure management studies. The table includes sources of data, sample sizes, and econometric methods employed as well as succinct summaries of the major findings of each study.

\section{Financial disclosure management to improve performance measures: donations market and contracting motivations}

Section 2.3 discussed incentives to manage financial disclosures in order to maximize the program ratio or minimize the fundraising and administrative ratios to influence donations as well as compensation and debt contracts. Is there evidence that nonprofits manage their ratios? Moreover, how is this misreporting accomplished? Efficiency ratios are computed using the numbers reported on IRS Form 990 or audited financial statements. When classifying expenses as program, administrative, or fundraising (or for tax purposes, as pertaining to an exempt activity versus a taxable activity), it is frequently necessary to allocate common or joint costs. Because many nonprofits are small, personnel and facilities-related costs may need to be allocated among several expense classifications. There is little guidance regarding these allocations; in fact, charities have considerable discretion in determining how to allocate expenses among Form 990 functional categories for programs, administration, and fundraising (GAO, 2002). Research suggests that financial disclosure management may be accomplished through these expense allocations: firms may over-allocate expenses to program services (Jones \& Roberts, 2006; Keating et al., 2008; Krishnan \& Yetman, 2011; Krishnan et al., 2006; Trussel, 2003). A related strategy to increase the program ratio (or decrease the fundraising ratio) is to misclassify fundraising expenses as program service expenses or to misallocate joint costs to program services (Jones \& Roberts, 2006; Keating et al., 2008; Khumawala, Parsons, \& Gordon, 2005; Krishnan et al., 2006; Tinkelman, 2009).

\subsection{Identifying potential disclosure management using performance ratios}

Is it possible to identify financial disclosure management by examining performance ratios? Baber et al. (2001), using a Jones-type prediction model, investigate large differences between predicted and actual program spending and find at least one organization that seems to be engaging in blatant disclosure management. Using similar methodology, Trussel (2003) finds that the likelihood of a charity being a potential accounting manipulator-having a higher-than-expected program ratio-is associated with a lower surplus margin, lower deferred revenues and expenses (immediate recognition of a program expense inflates the program ratio), more depreciation allocated to programs (faster depreciation write-offs inflate the program ratio), and bigger positive changes in the program ratio. The classification of any nonprofit with a large prediction error as a potential manipulator seems rather arbitrary, since it disallows the possibility that some nonprofits are exceptionally efficient (see the discussion of Jones-type models in Section 3.2).

Bhattacharya and Tinkelman (2009) fail to find evidence of manipulation of reported ratios to just meet (rather than just fail) CBBB standards. Their frequency distributions of reported program ratios, fundraising ratios, and management ratios show no unusual clustering of observations close to the cut-off levels dictated by CBBB guidelines. Krishnan and Yetman (2011) find that nonprofit hospitals in California report an average program ratio of 77.4 percent to the state regulatory agency, compared to 86.5 percent on the Form 990 , which suggests that the numbers most likely to be seen by the public are being managed upwards. 
Table 2

Summary of research on financial disclosure management in nonprofit organizations (presented in the order in which the papers appear in this review).

\begin{tabular}{|c|c|c|c|}
\hline Authors (year) & Focus of study (database) sample size & Method, financial disclosure variable & Summary of major findings \\
\hline \multicolumn{4}{|c|}{ Panel A: research involving donations market and contracting motivations (Section 4) } \\
\hline Baber et al. (2001) & $\begin{array}{l}\text { Charitable nonprofits (hand-collected } \\
\text { Form } 990 \text { tax returns) } \\
1239 \text { org/years }\end{array}$ & $\begin{array}{l}\text { Jones-type model } \\
\text { Program ratio }\end{array}$ & $\begin{array}{l}\text { Program ratio varies between revenue maximizer } \\
\text { and cost minimizers; firms with program ratios } \\
\text { higher than predicted by the model are investigate } \\
\text { and irregularities are found }\end{array}$ \\
\hline Trussel (2003) & $\begin{array}{l}\text { Nonprofits (NCCS/IRS 1997-1998) } \\
8496 \text { org/years }\end{array}$ & $\begin{array}{l}\text { Jones-type model } \\
\text { Program ratio }\end{array}$ & $\begin{array}{l}\text { A model is developed a model for identifying } \\
\text { potential accounting manipulators. Such firms ten } \\
\text { to have high program ratios, lower margins, less } \\
\text { deferred revenues and expenses, and more progra } \\
\text { depreciation }\end{array}$ \\
\hline Bhattacharya and & Nonprofits (NCCS-GuideStar 2001) & Distributional analysis & No unusual clustering of ratios is found at or near \\
\hline Tinkelman (2009) & 111,000 organizations & Program, fundraising, management ratios & CBBB-guideline cutoff points \\
\hline Krishnan et al. (2006) & $\begin{array}{l}\text { Nonprofits reporting zero fundraising } \\
\text { expenses (NCCS 1998) } \\
4995 \text { organizations }\end{array}$ & $\begin{array}{l}\text { Regression analysis } \\
\text { Fundraising expenses }\end{array}$ & $\begin{array}{l}\text { Nonprofits inappropriately shift expenses from } \\
\text { fundraising to program services. Expense } \\
\text { misreporting is associated with compensation and } \\
\text { donation sensitivity to the program ratio }\end{array}$ \\
\hline Keating et al. (2008) & $\begin{array}{l}\text { Charities reporting telemarketing to } \\
\text { states (state agencies, NCCS } 1994- \\
2004 \text { ) } \\
4248 \text { organizations }\end{array}$ & $\begin{array}{l}\text { Logistic regression analysis } \\
\text { Fundraising (telemarketing) expenses }\end{array}$ & $\begin{array}{l}74 \text { percent of nonprofit regulatory filings misrepo } \\
\text { telemarketing expenses. A negative association is } \\
\text { found between certain attributes (firm size, extern } \\
\text { monitoring, accounting expertise) and misreporti } \\
\text { telemarketing expenses }\end{array}$ \\
\hline $\begin{array}{l}\text { Jones and Roberts } \\
\text { (2006) }\end{array}$ & $\begin{array}{l}\text { Charities that report joint costs } \\
\text { (Maryland Charitable Organization } \\
\text { Division) } \\
708 \text { org/years }\end{array}$ & $\begin{array}{l}\text { Regression analysis } \\
\text { Changes in joint-cost ratio and in share of joint } \\
\text { costs allocated to programs }\end{array}$ & $\begin{array}{l}\text { Changes in the joint-cost ratio vary inversely with } \\
\text { changes in the direct-program ratio and with } \\
\text { changes in the share of joint costs allocated to } \\
\text { programs. Both results are consistent with joint cos } \\
\text { being manipulated to smooth the program ratio }\end{array}$ \\
\hline Tinkelman (2009) & $\begin{array}{l}\text { Avon Foundation (privately obtained } \\
\text { data) }\end{array}$ & $\begin{array}{l}\text { Field study } \\
\text { Allocations of joint costs }\end{array}$ & $\begin{array}{l}\text { Avon allocated fundraising costs to programs in } \\
\text { order to meet CBBB guidelines for fundraising and } \\
\text { program ratios }\end{array}$ \\
\hline Parsons et al. (2012) & $\begin{array}{l}\text { Nonprofit managers (hand-collected } \\
\text { survey data) } \\
238 \text { organizations }\end{array}$ & $\begin{array}{l}\text { Survey and regression } \\
\text { Reporting of administrative expenses }\end{array}$ & $\begin{array}{l}\text { Executives admit to managing efficiency ratios by } \\
\text { adjusting real transactions as well as by cost-shiftin } \\
\text { administrative expenses. The belief that efficiency } \\
\text { ratios affect funding increases the likelihood of suc } \\
\text { behavior }\end{array}$ \\
\hline \multicolumn{4}{|c|}{ Panel B: research involving political cost, regulatory, and tax motivations } \\
\hline $\begin{array}{l}\text { Chase and Coffman } \\
\text { (1994) }\end{array}$ & $\begin{array}{l}\text { Colleges and universities (U.S. Dept. of } \\
\text { Education data and survey 1989) } \\
170 \text { institutions }\end{array}$ & $\begin{array}{l}\text { OLS regression } \\
\text { Choice of cost or fair value accounting for } \\
\text { investments }\end{array}$ & $\begin{array}{l}\text { Choice of accounting method for investments is } \\
\text { influenced by political costs and managerial } \\
\text { compensation contracts }\end{array}$ \\
\hline
\end{tabular}

Choice of cost or fair value accounting for
investments compensation contracts 
Table 2 (Continued)

\begin{tabular}{|c|c|c|c|}
\hline Authors (year) & Focus of study (database) sample size & Method, financial disclosure variable & Summary of major findings \\
\hline $\begin{array}{l}\text { Christensen and } \\
\text { Mohr (1995) }\end{array}$ & $\begin{array}{l}\text { Art museums (National Museum } \\
\text { Survey 1989) } \\
106 \text { org }\end{array}$ & $\begin{array}{l}\text { Logistic regression } \\
\text { Choice to capitalize permanent collection }\end{array}$ & $\begin{array}{l}\text { Capitalization is negatively associated with size and } \\
\text { with federal government support, both measures of } \\
\text { political cost }\end{array}$ \\
\hline Hoerger (1991) & $\begin{array}{l}\text { Hospitals (Healthcare Financing } \\
\text { Administration, AHA 1983-1988) } \\
\text { 13,902 org/years }\end{array}$ & $\begin{array}{l}\text { Regression } \\
\text { Actual minus predicted profits }\end{array}$ & $\begin{array}{l}\text { Not-for-profit hospitals experienced significantly } \\
\text { lower variation in profits than similar-size for-profit } \\
\text { hospitals during a period of large exogenous changes } \\
\text { in third-party reimbursement policy, suggesting that } \\
\text { earnings are being managed to meet a zero-profit } \\
\text { constraint }\end{array}$ \\
\hline Mensah et al. (1994) & $\begin{array}{l}\text { HMOs (Healthcare Investment } \\
\text { Analysts' database 1986-1989) } 455 \\
\text { organizations }\end{array}$ & $\begin{array}{l}\text { Jones-type model Accruals of incurred-but- } \\
\text { not-reported (IBNR) expenses }\end{array}$ & $\begin{array}{l}\text { HMO managers may overstate IBNR expenses to } \\
\text { mitigate any adverse effects of public policy for } \\
\text { having above-normal earnings. Results for nonprofit } \\
\text { subsample are qualitatively similar to those of for- } \\
\text { profit HMOs }\end{array}$ \\
\hline $\begin{array}{l}\text { Leone and Van } \\
\text { Horn }(2005)\end{array}$ & $\begin{array}{l}\text { Nonprofit hospitals (Van Kampen } \\
\text { Merritt 1990-2002) } \\
\text { 8179org/years }\end{array}$ & $\begin{array}{l}\text { Jones-type model } \\
\text { Discretionary spending and discretionary } \\
\text { accruals }\end{array}$ & $\begin{array}{l}\text { Nonprofit hospitals adjust discretionary spending } \\
\text { (including charity care) and discretionary accruals to } \\
\text { minimize changes in earnings and to maintain a } \\
\text { small positive amount of margin }\end{array}$ \\
\hline $\begin{array}{l}\text { Ballantine et al. } \\
\text { (2007) }\end{array}$ & $\begin{array}{l}\text { English NHS Trust hospitals (Laing and } \\
\text { Buisson 1998-2004) } \\
1372 \text { org/years }\end{array}$ & $\begin{array}{l}\text { Distributional analysis } \\
\text { Residual income } \\
\text { Jones-type model } \\
\text { Discretionary accruals }\end{array}$ & $\begin{array}{l}\text { Highly significant discontinuity in the distribution of } \\
\text { residual income, with } 52 \text { percent of all observations } \\
\text { in the first interval above zero. Discretionary accruals } \\
\text { are negatively associated with non-discretionary } \\
\text { income }\end{array}$ \\
\hline $\begin{array}{l}\text { Eldenburg et al. } \\
\text { (2011) }\end{array}$ & $\begin{array}{l}\text { Nonprofit hospitals (California OSHPD } \\
\text { 1998-2003) } \\
432 \text { org/years }\end{array}$ & $\begin{array}{l}\text { Multivariate regressions } \\
\text { Changes in expenditures }\end{array}$ & $\begin{array}{l}\text { Managers engage in real activity management to } \\
\text { meet earnings benchmarks (zero-profit constraint) } \\
\text { via both expenditure manipulation and asset } \\
\text { management. Managers also manage income } \\
\text { upward to increase compensation. Most real activity } \\
\text { earnings management involves non-operating and } \\
\text { non-revenue-generating activities }\end{array}$ \\
\hline $\begin{array}{l}\text { Krishnan and Yetman } \\
\text { (2011) }\end{array}$ & $\begin{array}{l}\text { Not-for-profit hospitals (California } \\
\text { OSHPD and IRS 1989-2005) } \\
620 \text { org/years }\end{array}$ & $\begin{array}{l}\text { Regression } \\
\text { Differences in program ratios between OSHPD } \\
\text { and IRS reports }\end{array}$ & $\begin{array}{l}\text { Normative institutional pressures (rural, church- } \\
\text { related, charity, or system hospitals) are associated } \\
\text { with higher cost-shifting, while regulative } \\
\text { institutional pressures (high proportion of Medicare/ } \\
\text { Medicaid revenue) reduce the extent of cost-shifting }\end{array}$ \\
\hline $\begin{array}{l}\text { Eldenburg and } \\
\text { Vines (2004) }\end{array}$ & $\begin{array}{l}\text { Not-for-profit hospitals (Florida Agency } \\
\text { for Health Care Admin. 1989-1991) } \\
98 \text { organizations }\end{array}$ & $\begin{array}{l}\text { Regression } \\
\text { Change in bad debts expense }\end{array}$ & $\begin{array}{l}\text { Hospitals in a better cash position are more likely to } \\
\text { reclassify bad debts as charity care (but no evidence } \\
\text { that hospitals with low levels of charity care } \\
\text { reclassify bad debts to charity care). High cash, low- } \\
\text { operating-margin hospitals are most likely to } \\
\text { reclassify }\end{array}$ \\
\hline
\end{tabular}


$1063 \mathrm{org} /$ years

Cordes and Weisbrod (1998)

Sansing (1998)

Yetman (2001)

Omer and Yetman (2003)

Hofmann (2007)

Omer and Yetman (2007)

Yoder et al. (2011)

Nonprofits (IRS data 1990-1993) 9104 observations

Nonprofits with unrelated business activities

501(c)(3) nonprofits (hand collected data 1995-1997)

1824 org/years

501(c)(3) nonprofits (hand collected data 1995-1997)

1367 org/years

Trade associations (survey, IRS 19941997)

399 org/years

501(c)(3) nonprofits (hand-collected

data 1994-1998

1667 org/years

Private foundations (IRS/NCCS 1994

2006)

23,688 org/years

Panel C: research involving consequences and remedies

Buchheit and Parsons

Potential donors (college students)

157 participants

Parsons (2007)

Khumawala et al. (2005)
Potential donors

8022 fundraising letters, 238 business students

Joint cost disclosures (preparers, expert donors, students)

125 participants
Jones-type models

Discretionary accruals

Unexpected charity care

Regressions

UBI, performance ratios, compensation

expense

Analytical model

Expenses of unrelated business activities

\section{Regression}

Allocation of expenses to unrelated business activities

Distributional analysis

Reported profitability of taxable activities

Regression

Allocation of expenses to unrelated business activities

Regression

Allocation of expenses to unrelated business activities

Logistic regression

Failing or barely meeting benchmark for

taxation

Laboratory experiment

Choice to donate

Field and laboratory experiments Likelihood of donating

\section{Experiment}

Joint cost allocations

Choice to donate
Managers make more income-increasing accruals when charity care is higher than expected and manage positive earnings toward zero more aggressively when charity care is below expectation Nonprofits in high-tax states are more likely to have UBI. Nonprofits with UBI have lower management ratios. Increases in UBI do not increase total compensation costs but increase compensation allocated to the taxable activities

If exempt organizations are permitted to allocate common costs to taxable activities in excess of economic marginal costs, UBIT will fail to deter economically inefficient investments by nonprofits Firms over-allocate expenses to taxable activities to reduce taxable profits

An abnormally large number of firms report nearzero profits on their taxable activities

Firms over-allocate expenses to taxable activities to reduce taxable profits

Nonprofits' misreporting of expenses is increasing in tax rates, tax-return complexity, and accounting flexibility and decreasing in detection risk

Foundations use tax-motivated allocations to barely qualify for reduced tax rates on undistributed income

Only 39 percent of subjects asked for financial information to assist with the donation decision; 89 percent of those viewing such information donated to the organization with the highest program ratio Donors who have previously donated are more likely to respond to an appeal that includes financial accounting information. Nonfinancial information (SEA) can enhance donor perceptions

Participants appear to ignore the effects of allocated joint costs on program ratios. Little evidence that joint cost disclosures are used to adjust reported fundraising/program expenses 
Table 2 (Continued)

\begin{tabular}{|c|c|c|c|}
\hline Authors (year) & Focus of study (database) sample size & Method, financial disclosure variable & Summary of major findings \\
\hline $\begin{array}{l}\text { Yetman and Yetman } \\
(2013)\end{array}$ & $\begin{array}{l}\text { Donor reactions to disclosure } \\
\text { management (NCCS/IRS 1982-2007) } \\
\text { 37,349org/years }\end{array}$ & $\begin{array}{l}\text { Regression } \\
\text { Private donations }\end{array}$ & $\begin{array}{l}\text { Donors discount program ratios of organizations } \\
\text { reporting zero fundraising, especially after Form } 990 \\
\text { became publicly available. Sophisticated donors also } \\
\text { discount program ratios when fundraising or } \\
\text { administrative expenses appear to be understated }\end{array}$ \\
\hline $\begin{array}{l}\text { Thornton and Belski } \\
\text { (2010) }\end{array}$ & $\begin{array}{l}\text { Reporting quality (NCCS 1998-2002) } \\
352,812 \text { org/years }\end{array}$ & $\begin{array}{l}\text { Regression } \\
\text { Direct support }\end{array}$ & $\begin{array}{l}\text { Firms with higher reporting quality (professional } \\
\text { accountant, single audit, indirect support, SOP } 98-2 \\
\text { compliant) are associated with increases in } \\
\text { donations }\end{array}$ \\
\hline Grein and Tate (2011) & $\begin{array}{l}\text { Public housing authorities (HUD 2001- } \\
2007 \text { ) } \\
\text { 19,569 org/years }\end{array}$ & $\begin{array}{l}\text { Univariate and regression analysis } \\
\text { Auditor adjustments }\end{array}$ & $\begin{array}{l}\text { Auditors make significant material adjustments to } \\
\text { financial statements, consistent with reducing } \\
\text { managerial bias to meet HUD performance criteria }\end{array}$ \\
\hline $\begin{array}{l}\text { Yetman and Yetman } \\
\text { (2011) }\end{array}$ & $\begin{array}{l}\text { Governance mechanisms (NCCS/IRS } \\
\text { 1992-2006 GuideStar 2008) }\end{array}$ & $\begin{array}{l}\text { Regressions, Jones-type models } \\
\text { Program expense accuracy }\end{array}$ & $\begin{array}{l}\text { Governance mechanisms (independent directors, } \\
\text { audits, donor restrictions, state regulation, SOX-style } \\
\text { policies, etc.) are positively associated with the } \\
\text { accuracy of reported program expenses }\end{array}$ \\
\hline
\end{tabular}




\subsection{Disclosure management by misreporting non-program expenses}

A nonprofit can increase the amount of program services it reports by misclassifying fundraising or administrative expenses as program service expenditures, simultaneously improving the program ratio and the fundraising or management ratio. Seventy-five percent of the 111,000 Forms 990 filed in 2001 included in the NCCS Core database report either zero fundraising or zero administrative expenses (Bhattacharya \& Tinkelman, 2009). A close look at the websites for a sample of such nonprofits reveals evidence of fundraising activities that would incur reportable fundraising expenses (for example, solicitation materials or fundraising personnel) (Krishnan et al., 2006). Comparisons of audited financial statements with matching Forms 990 also find significant differences in reported fundraising expense amounts-38 percent of the nonprofits in one study report less fundraising expense on their IRS Form 990 than in their audited statements (Krishnan et al., 2006). Likewise, a comparison of telemarketers' campaign reports filed with state regulatory agencies to the associated amounts reported by nonprofits on their IRS Forms 990 finds that 74 percent of the Forms 990 fail to properly report telemarketing expenses, with the result that the fundraising ratio could be understated by as much as 15 percent (Keating et al., 2008). ${ }^{12}$

\subsection{Misallocation of joint costs}

Charities frequently combine fundraising efforts with other activities (e.g., a cancer research charity might include an educational brochure about recognizing the signs of skin cancer with the charity's annual fundraising appeal). Such combinations are referred to as joint activities. Generally, the costs of joint activities are reported as fundraising expenses under the supporting services category. However, the FASB (2009) has allowed such costs to be allocated among specific program and supporting service functions. ${ }^{13}$ From an auditing standpoint, the American Institute of Certified Public Accountants (AICPA) has wrestled with this issue for decades-its Statement of Position (SOP) 87-2 (AICPA, 1987) included guidance for joint cost allocations, but there was concern that the standard failed to provide auditors with objectives for evaluating the reasonableness of allocations (Capin \& Tanenbaum, 1998; Tishlias, 1992). To report any of the costs as program expenses, the AICPA's SOP 98-2 (AICPA, 1998) requires that a joint activity must meet three criteria as defined in the SOP: purpose, audience, and content. The standard, however, neither prescribes nor prohibits specific allocation methods. Thus, the allocation of joint costs still provides an opportunity for nonprofits to manage reported program expenses.

Several studies have found compelling evidence that nonprofits manage the allocation of joint costs in order to achieve certain performance benchmarks (Jones \& Roberts, 2006; Tinkelman, 2009). Of course, it is not always possible to determine whether changes observed in the amount or allocation of joint costs result from real, strategic changes in public education and fundraising activities or from accounting changes in the classification or allocation of joint costs. Only about two percent of nonprofits report joint costs (Krishnan et al., 2006), so any sample studied will necessarily be small and biased toward larger organizations.

\subsection{Misreporting administrative expenses}

Another way to improve the program ratio is to forgo administrative or fundraising expenses. While most of the studies that test for disclosure management have focused on misreporting or

\footnotetext{
${ }^{12}$ Nonprofits can misreport telemarketing in one of three ways: they can report proceeds from the campaign net of the fees paid to the telemarketer, rather than gross proceeds with an offsetting expense elsewhere on the return; or report the telemarketing expenses on a line other than "professional fundraising;" or allocate some or all of the telemarketing fees to a classification other than fundraising.

${ }^{13}$ FASB, Accounting Standards Codification, section 958-720-45 (FASB, 2009). Costs of joint activities may be allocated among functions (fundraising, program, management and general) as appropriate provided all three of the following criteria are met. (1) The activity requires specific action by the audience that helps accomplish the organization's mission. (2) The activity's audience is not selected on its ability or likelihood to make contributions. (3) The activity motivates the audience to take specific actions, beyond making contributions, that helps accomplish the organization's mission. If one of the criteria is not met, then all joint activity costs, except costs of exchange transactions that directly benefit donors, must be reported as fundraising expenses.
} 
misallocating fundraising expenses, one recent study (Parsons et al., 2012) looks at motivations for and incidence of misreporting administrative expenses. While cost-cutting is not disclosure management per se, cost-cutting that improves ratios in the short run but negatively affects the long-run viability of the nonprofit is not in the best interest of the stakeholders. Parsons et al. (2012) is the first study to ask nonprofit managers whether they have or would be willing to manage efficiency ratios or alter spending decisions in order to meet targets. Thirty-five percent of managers admit to altering spending for administrative items such as hiring or training staff and upgrading computer hardware or software. Twenty percent admit to having altered cost allocations to meet target ratios, and 35 percent indicate they use their current allocation method specifically to meet target efficiency ratios. When facing a hypothetical situation where program spending at year-end is less than expected, at least half of the respondents indicated that they would be "very likely" or "somewhat likely" to accelerate program spending, forgo administrative or fundraising spending, or revise expense allocations.

Managers express greater likelihood to engage in disclosure management when they have incentives to do so-a belief that they are being evaluated on their efficiency ratios or that they will lose contribution or grant money if their administrative ratio is too high (Parsons et al., 2012). Managers also indicate greater likelihood of managing efficiency ratios in the future if they have admitted to doing so in the past. The Parsons et al. (2012) study is, of course, subject to the limitations of survey research: low response rate with its potential for sample selection bias, inability to ensure that the questions were answered truthfully and by the appropriate party, uncertainty as to whether expressed intentions in a hypothetical situation correspond to actual behavior, etc. However, the survey responses leave little doubt that some nonprofit executives feel pressure to meet financial benchmarks and are willing to do (or at least to consider) what it takes to protect their funding (or their jobs), including altering spending decisions and changing cost allocations.

\section{Disclosure management to minimize reported wealth or profits: political cost, regulatory and tax motivations}

Regulation and taxation also create incentives for financial disclosure management. Nonprofit hospitals are monitored by state regulators interested in assuring that the hospital is maintaining its eligibility for tax exemption and is providing a sufficient level of charity care (Kane, 2007). A sudden increase in profits or in the program ratio of any charitable organization may raise the suspicion of watchdog groups or state or federal regulators (Jones \& Roberts, 2006). Grein and Tate (2011) find that public housing authorities, which are subject to monitoring by the federal Department of Housing and Urban Development (HUD), have incentives to manage financial disclosures to qualify for less intense oversight. Nonprofits engaging in taxable activities have an incentive to manipulate cost allocations in order to minimize tax liabilities (Jegers, 2010; Sansing, 1998; Yoder, Addy, \& McAllister, 2011). ${ }^{14}$ If government and industry regulators are considered stakeholders or users of financial information from nonprofits, then misreporting financial information in order to remain in compliance with regulations or to minimize tax liabilities is also a form of disclosure management.

\subsection{Political cost studies}

The desire to avoid political costs, such as increased scrutiny from regulators, and the desire to appear "worthy" to donors seem to create incentives to use more conservative accounting methods for asset valuation. This is in line with Marudas (2004) finding that higher reported wealth had a negative impact on private donations, at least among large arts and philanthropic nonprofits (although wealth had a positive relationship on private donations to large educational institutions). Colleges and universities can choose to account for their endowment assets using the cost method or the fair market value (FMV) method. In a rising stock market, FMV will produce higher earnings and higher

\footnotetext{
${ }^{14}$ Nonprofits are exempt from tax on their program-related activities, but are taxed on business activities that are unrelated to their mission. Private nonoperating foundations are also subject to taxes on undistributed income.
} 
asset values, but a Peat (1985) study revealed that 78 percent of colleges and universities use the cost method. Looking at schools with endowments of greater than \$1 million, Chase and Coffman (1994) observe that 36 out of 137 private institutions use FMV, while only three out of 33 public institutions do, which is consistent with publicly funded schools wanting to minimize reported earnings and wealth in order to avoid reductions in state funding. Private institutions with larger endowment holdings are more likely to choose the FMV method and to report higher mean investment returns. Chase and Coffman (1994) speculate that the size of an institution's endowment may serve as a signal to potential donors that others have recognized the institution's value and that gifts will be managed competently. This can explain why institutions with larger endowment funds are more likely to use FMV.

In 1990, the FASB issued an exposure draft that would require museums to capitalize their permanent artistic or historical collections. Due to strong negative reaction from the museum community, FASB backed away from the requirement and instead made it optional. Christensen and Mohr (1995) find a significant negative relationship between federal support and the decision to capitalize the permanent collection. This is consistent with museum managers holding the belief that reporting higher asset values might detract from the "worthiness" of the nonprofit and possibly dampen public support. Size, frequently used as a proxy for political costs, is also negatively related to capitalization in this study.

\subsection{The healthcare regulatory environment: managing profits toward zero}

There are a variety of reasons for nonprofit hospitals to avoid reporting losses. Hospital CEOs are often evaluated on financial performance (Brickley \& Van Horn, 2002), and the reporting of losses might negatively impact managerial compensation, reputation, and career mobility. Furthermore, many nonprofit hospitals finance capital expansion by issuing debt (Leone \& Van Horn, 2005) and may seek to avoid losses and to smooth earnings in order to reduce the cost of debt (Trueman \& Titman, 1988).

There are also important reasons for nonprofit hospitals to minimize reported profits. The existence of profits invites scrutiny from the IRS and state and local tax authorities. The U.S. Comptroller General, Congress, the IRS, and a number of states and municipalities have recently begun to question whether the difference between profit and nonprofit hospitals is large enough to justify granting tax-exemption to the latter group (Kane, 2007). The reporting of profits may suggest that the nonprofit hospital has not provided sufficient charitable services to the community (or that it is overcharging for its services) and may cast doubt on its worthiness for tax exemption. Methodist Hospital was sued by the Texas Attorney General soon after Modern Healthcare magazine named it the third most profitable nonprofit hospital system in 1991 (Leone \& Van Horn, 2005). In 2006, state attorneys general in Illinois, Kansas, and Minnesota were looking into possible abuses by tax-exempt hospitals, while other states were proposing legislation that would require minimum levels of charity care (Kane, 2007).

Another reason to minimize the appearance of profitability is that third-party payers may use the existence of profits as a reason to negotiate for price concessions from healthcare providers. There is a stream of research that examines cost-shifting by hospitals to maximize reimbursements from thirdparty payers or to avoid exceeding state-imposed revenue constraints. Eldenburg and Soderstrom (1996) and Eldenburg and Kallapur (1997) find evidence that both for-profit and nonprofit hospitals manage their patient mix, cost allocations, and budget estimates of patient volume and costs in order to increase revenues and maximize cash flows.

If nonprofit and governmental hospitals operate as if subject to a profitability constraint, their profits should show less variability over time than those of for-profit hospitals and less reaction to changes in exogenous factors like Medicare reimbursement rates. A study by Hoerger (1991) strongly supports both of those hypotheses. Variability is significantly less for nonprofit hospitals and even smaller for government hospitals, which likely face a real budget constraint on actual profits. In distributional analyses of nonprofit hospitals, Leone and Van Horn (2005) observe that the distribution of operating income has much less variability (smaller standard deviation) than earnings before discretionary accruals, suggesting that managers use discretionary accruals to moderate extreme 
values of operating income. ${ }^{15}$ In a histogram of residual income scaled by total assets, Ballantine, Forker, and Greenwood (2007) observe a significant discontinuity at zero, with a very large spike in the interval from zero to 0.02 percent. In fact, 52 percent of all hospitals in their study are in the first two intervals to the right of zero, consistent with managerial incentives to avoid losses and to minimize profits. ${ }^{16}$

Studies using variations of the Jones model to examine accruals manipulation by nonprofit healthcare institutions find evidence that managers of financially weak HMOs understate expense accruals to minimize the political costs associated with failure to meet state-mandated minimum net worth and cash reserve requirements while highly profitable HMOs attempt to reduce political visibility by managing earnings downward using income-decreasing accruals (Mensah, Considine, \& Oakes, 1994) and that nonprofit hospital CEOs adjust discretionary accruals, particularly the thirdparty adjustment account or allowance for bad debts, to decrease profits and losses (Ballantine et al., 2007; Leone \& Van Horn, 2005; Vansant, 2011).

In addition to accruals management, there is evidence that real activities are altered to manage net income toward a benchmark of zero. In particular, expenditures for non-operating and nonrevenue-generating activities, as well as asset dispositions, appear to be managed to avoid losses but minimize profits (Eldenburg, Gunny, Hee, \& Soderstrom, 2011). Furthermore, that study finds that firms with incentives to decrease (increase) expenditures in one year and no such incentive in the following year are more likely to reverse the decrease (increase) in the following year, suggestive of opportunism rather than managerial prudence. Charity care expenditures are found to be positively associated with profits before charity care, suggesting that hospitals adjust the provision of charity care to available resources and use it to minimize reported profits (Leone \& Van Horn, 2005). However, nonprofit hospitals that are already reporting adequate levels of charity care appear to be less aggressive in managing earnings toward zero (Vansant, 2011). This result implies that hospital management is less concerned about minimizing reported profits when adequate charity care is reported.

Nonprofit hospitals are expected not only to provide services that are inherently unprofitable for private enterprise but, in exchange for tax exemption, to use operating profits to provide free or discounted healthcare to the indigent and uninsured. It is the provision of charity care more than the absence of profits that justifies tax-exemption for nonprofit hospitals. ${ }^{17}$ In recent years, nonprofit hospitals have come under closer government scrutiny and regulation regarding their charity care. There are serious political costs for nonprofit hospitals that do not report sufficient charity care (Missouri Foundation for Health, 2005).

In 1990, hospital accounting guidelines changed to require the amount of charity care to be separately disclosed in a footnote rather than netted from gross income in aggregate with bad debts and other write-offs (Eldenburg \& Vines, 2004). Now that it is required that charity care be publicly disclosed, managers have incentives to overstate charity care or understate bad debts. Comparing amounts reported for charity care before and after this accounting change, Eldenburg and Vines (2004) find that while overall levels of uncompensated care did not change, the hospitals experienced a decline in bad debt expense as a percent of uncompensated care and as a percent of revenue. They also find a strong negative association between changes in bad debt expense and changes in charity care, which is highly suggestive of reclassification. ${ }^{18}$

\footnotetext{
${ }^{15}$ Leone and Van Horn (2005) also prepare a histogram of the distribution of one-year changes in reported operating income: it is symmetrical, centered at zero, and displays no discontinuity below zero. This result is different from what Burgstahler and Dichev (1997) observed in the for-profit setting, suggesting that nonprofit managers do not face the same pressure to report earnings growth.

${ }^{16}$ As the authors point out, the inclusion of the entire population of NHS hospital trusts in their study rules out the possibility of sample selection bias.

17 Technically, charity care includes all the costs and write-offs associated with services rendered to individuals determined prior to service delivery to be unable to pay (and who are not eligible for public assistance); it does not include bad debts (Missouri Foundation for Health, 2005).

18 Eldenburg and Vines (2004) are able to exploit a private database, from the Florida Agency for Health Care Administration (FAHCA), which allows each observation to serve as its own control. FAHCA requires annual budget and financial statement information from all nonfederal hospitals in the state. These data have always included separate disclosure of charity care expenses, but are not publicly available.
} 


\subsection{Misreporting to minimize taxes}

There is a significant body of research regarding the taxation of tax-exempt nonprofits, and the tax avoidance and evasion strategies that such taxation induces. Most of these studies center on the Unrelated Business Income Tax (UBIT). The fact that UBI is taxed at corporate rates would presumably discourage nonprofits from venturing in that direction, unless the nonprofit can exploit existing facilities and allocate some of the costs of exempt activities to the commercial activity. This tactic will increase the apparent efficiency of the exempt activity and minimize taxes on the taxable activity. Analytical modeling can be used to show that UBIT can effectively promote productive efficiency (deterring nonprofits from engaging in such activities when there is a comparative disadvantage, without deterring investment when there is a comparative advantage), but only if the costs deducted to arrive at taxable income reflect the true economic costs of the activity (Sansing, 1998). If a nonprofit is able to apply a cost allocation method that allocates enough of the organization's common costs to the unrelated activity to eliminate any taxable income, the expenses deducted will not necessarily reflect the true incremental economic costs of the activity, and UBIT will fail to ensure productive efficiency.

Much of the evidence that nonprofits over-allocate expenses to unrelated business activities is circumstantial. For example, nearly 60 percent of nonprofits filing UBIT returns in 1991 report losses from those activities (Cordes \& Weisbrod, 1998). While it is reasonable to assume that nonprofits engage in taxable activities to help fund their exempt activities, one must question a nonprofit's motivation for engaging in unprofitable business ventures. Nonprofit associations with unrelated business activities are more profitable overall (measured by the surplus of total revenues over total expenses) than those without such activities (Hofmann, 2007), yet most of those taxable activities show no profits. These statistics are most easily explained as evidence of cost-shifting.

Is there more direct empirical evidence of cost-shifting to avoid UBIT? Lacking detailed information regarding actual resource usage of taxable activities or exempt activities, Yetman (2001) develops a prediction model based on the assumption that the expenses of the nonprofits' various activities are proportional to the revenues generated by each. A regression of the change in expenses on changes in revenues yields variable expense ratios, which are used to predict the variable expenses that should be allocated to taxable activities. Remaining (fixed) costs are allocated proportionally to revenues. The difference between reported expenses and total predicted expenses for the taxable activities is taken as an estimate of expense-shifting. Yetman finds significant results for educational nonprofits (23 percent of reported expenses are in excess of predicted) and for medical nonprofits (62 percent of reported expenses are in excess of predicted) but not for charitable nonprofits. Hofmann (2007) replicates Yetman's (2001) study on a different population of nonprofits, trade and professional associations, and finds 20-36 percent of reported expenses for unrelated activities are in excess of predicted expenses. However, upon closer analysis of the prediction model, Hofmann questions its validity and concludes that the variable cost ratios estimated by the model are likely overstated and that cost-shifting is likely understated in both studies. Taking a different approach, Omer and Yetman (2003) use a distributional analysis and find a notable discontinuity in the interval from negative one percent to one percent: a statistically abnormal number of nonprofits report taxable income near zero.

Unrelated business activities, because they utilize existing facilities and personnel, often have no marginal costs (Cordes \& Weisbrod, 1998). From an economic perspective, the allocation of any expenses to those activities is deemed cost-shifting. The previous empirical studies suggest that the expenses reported on IRS Form 990-T might exceed the true incremental costs of the unrelated business activity but do not necessarily prove that nonprofits are engaging in illegal tax evasion. Treasury Regulation 1.512(a)-1 is rather lenient in its instructions as to appropriate allocations of common costs to unrelated activities. Omer and Yetman (2007) attempt to find evidence of misreporting that could be characterized as tax evasion. Using the tax returns collected for Yetman's 2001 study, Omer and Yetman (2007) identify those firms that reported advertising, exploited, or debt-financed activities. ${ }^{19}$ Tax laws strictly limit the deductible amounts of expenses for these three types of taxable activities. They find that 19 percent of their observations over-report their taxable

\footnotetext{
${ }^{19}$ Exploited activities occur when a nonprofit exploits an intangible, for example its name or logo, for commercial purposes.
} 
expenses in those areas by an average of 30 percent, thereby creating net operating losses (NOLs) when the rules preclude a taxable income amount less than zero. Unfortunately, as Schmidt (2007) points out, Omer and Yetman's measure of misreporting may simply represent tax preparer error: the instructions for the schedules accompanying IRS Form 990-T are not very clear. Furthermore, unless the overstated expenses are carried forward to subsequent tax periods and used to offset taxable income in the future, they do not really represent tax evasion but simply a reporting error, since the firms are allowed to reduce their taxable income to zero.

UBIT is not the only tax levied on nonprofit organizations. Private foundations are subject to several excise taxes; one in particular is designed to encourage annual distributions (Sansing \& Yetman, 2006). The Investment Income Tax (IIT) is an excise tax of two percent of net investment income. The IIT rate can be reduced to one percent if the foundation distributes an amount equal to or exceeding a threshold. ${ }^{20}$ Since current-year amounts are used in the calculation of the threshold, foundations must estimate the minimum distribution required to qualify for the lower tax rate. If a foundation is unable or unwilling to distribute sufficient cash in a given year or finds itself short of the threshold at the end of the year, it may increase qualifying distributions by allocating higher amounts of general and administrative expenses to qualifying distributions, or it may set aside amounts from future distributions to be used toward meeting current minimums. ${ }^{21}$ Thus, foundation managers have the flexibility to allocate across expense categories and across time. Yoder et al. (2011) examine a balanced panel of 1974 private foundations over a 12-year period and find evidence that foundations make allocations from investment expenses to qualifying distributions and recognize future qualifying distributions in the current year to just qualify for the 1 percent IIT.

\section{Research involving consequences and remedies}

Throughout the nonprofit disclosure management literature, researchers underscore the potential negative consequences of inaccurate financial reporting. If donors use the program ratio to help make allocation decisions, then distortions in that ratio will result in a misallocation of resources among nonprofits. This conclusion assumes, however, that donors actually use accounting information (which is not the same as saying that donations are correlated with program ratios) and that they are unable to detect disclosure management or to make adjustments for it. A number of studies focus on the reaction of donors (or donations) to performance ratios. While the ability to avoid UBIT and IIT by the use of cost allocations undermines the government's objectives for those taxes, there is little evidence as to the consequences this might have on the federal budget or the overall economy.

\subsection{Do donors use accounting information when making donation decisions?}

In an experiment using business students as subjects (and subject to all the limitations inherent in such studies), Buchheit and Parsons (2006) find that fewer than half the participants who had made a decision to donate were willing to view comparative financial information to ensure their donation was going to the most efficient anonymous charity. Of those who chose to view the financial summaries, however, 89 percent made their donation to the charity with the highest program ratio. In a field experiment involving a fundraising appeal for an actual local charity, the probability of making a donation was positively related to receiving accounting information but only for donors who had previously given to the organization (Parsons, 2007). In a follow-up lab experiment, students were asked to evaluate the usefulness of various disclosures. Prospective donors found fundraising appeals more informative if they included accounting or service effort and accomplishment disclosures.

\footnotetext{
${ }^{20}$ See IRC 4940(c) and associated Treasury Regulation.

${ }^{21}$ For tax purposes, general and administrative expenses are allocated between investment expense and qualifying distributions.
} 


\subsection{Are users (donors) misled by financial disclosure management?}

Khumawala et al. (2005) utilize a controlled experiment in which participants are asked to allocate $\$ 25,000$ between two competing medical research charities. They are given financial statements of both charities as well typical fundraising materials. Both charities disclose a $\$ 2$ million joint advertising/public education campaign. "Organization Q" inappropriately classifies the bulk of the joint costs as program services and consequently has a higher program ratio. If the allocations are undone and the joint costs are reclassified as fundraising, "Organization P" actually has the higher program ratio. Although all amounts and allocations are disclosed, the participant-donors allocate more money more frequently to Organization Q. Experienced donors and preparers are actually more likely to accept the reported joint cost allocations than the novice donors among the participants. ${ }^{22}$ When asked about the usefulness of various disclosures, participants seldom indicate that the joint cost allocation footnote is influential to the donation decision.

These studies suggest that small donors, at least, do not use accounting information effectively. Although donors say they value accounting information, they do not appear to be willing to expend much time or effort to obtain it. When they consider accounting information, both experienced and inexperienced donors seem to focus on the program ratio, taking the reported numbers at face value. This suggests that small donors who use accounting information can be misled by misreported numbers and may not allocate their donations to the most efficient charities. ${ }^{23}$

Other studies lead to a slightly more optimistic view of the users of nonprofit accounting information. Yetman and Yetman (2013) estimate that the average donor discounts the program ratio by 40 percent when zero fundraising expenses are reported, an obvious red flag for disclosure management. They also observe that sophisticated donors (those who make restricted donations) have more incentive or ability to recognize low reporting quality. Another important finding of their study is that donor reaction to potential accounting manipulation (as measured by zero fundraising expenses) increased markedly after 1998, when IRS Form 990 became readily accessible to donors on the GuideStar website. Overall, the market seems to reward nonprofits that have higher quality accounting disclosures on IRS Form 990. Firms that pay professional accounting fees or undergo a single audit, those receiving support indirectly through feeder agencies like the United Way, and firms checking the box to indicate compliance with SOP 98-2 all receive larger donations, ceteris paribus (Thornton \& Belski, 2010).

\subsection{What can be done to limit harmful disclosure management?}

The research reviewed in this paper has revealed a number of factors that appear to mitigate financial disclosure management: use of accrual accounting or professional outside accountants (Keating et al., 2008; Krishnan \& Yetman, 2011; Thornton \& Belski, 2010), professional management (Krishnan \& Yetman, 2011; Tinkelman, 1999), and larger size (Tinkelman, 1999). These findings could be interpreted to suggest that some of what has been identified as disclosure management is actually a result of lack of accounting expertise, not intentional misreporting. On the other hand, a more complex donor pool (receipt of restricted donations) (Keating et al., 2008; Yetman \& Yetman, 2013), greater external monitoring (Keating et al., 2008; Krishnan \& Yetman, 2011; Thornton \& Belski, 2010), external audits (Grein \& Tate, 2011; Thornton \& Belski, 2010), and tighter regulation (enactment of SOP 98-2) (Jones \& Roberts, 2006) have all been shown to be negatively associated with disclosure management, suggesting that even intentional misreporting can be reduced by increased regulation and oversight. Yetman and Yetman (2011) find that a number of governance variables are positively associated with more accurate reporting. They conclude that measures such as requiring audits, increasing state regulation and enforcement, and requiring SOX-type provisions such as audit

\footnotetext{
${ }^{22}$ Before SOP 98-2 became effective, Tinkelman (1998) found evidence that experienced donors were skeptical of joint cost allocations, and that unsophisticated donors were more likely to accept reported amounts as given.

${ }^{23}$ Less than one percent of nonprofits report joint costs, however, so it is not clear that the results of Tinkelman (1998) or Khumawala et al. (2005) are generalizable to other nonprofits or to other types of misreporting.
} 
committees, written policies, and a greater number of independent board members can improve the accuracy of Form 990.

Table 2 summarizes the papers discussed in Sections 4-6, showing for each paper the focus of the study, sources and time period for the data, sample size, statistical methodology, financial disclosure variable(s) of interest, and a brief summary of the results.

\section{Summary and suggestions for future research}

When all is said and done, what is really known about disclosure management in the nonprofit sector? There are tentative answers to at least a few basic questions. Why would nonprofits engage in earnings management? At the most fundamental level, nonprofit managers may attempt to mislead their board of trustees regarding how well they have fulfilled their stewardship function in order to protect their position or reputation or to increase their compensation. Managers may attempt to mislead donors, rating agencies, grantors, and the general public about how efficiently and effectively they are accomplishing their organization's philanthropic mission, or about how worthy the organization is, in order to garner more donations or grants. Nonprofit managers may attempt to mislead the IRS regarding their organization's qualification for tax-exempt status or liability for unrelated business income tax and to mislead state regulatory agencies to justify the right of the organization operate as a nonprofit and to solicit funds in the state.

How do nonprofits manage their financial disclosures? The existing literature identifies some management of real transactions-curtailing spending on administrative expenses, for example-and strategic accounting choices related to asset valuation, but for charities the primary means of accomplishing financial disclosure management seems to be the misclassification of costs and the over- or under-allocation of joint costs to programs or fundraising. Nonprofits are most likely to overreport amounts spent on programs or under-report amounts spent on fundraising in order to increase the program ratio (program expenses as a percentage of total expenses) or decrease the fundraising ratio (fundraising expenses as a percentage of donations received). In nonprofit hospitals, there is evidence of the management of discretionary accruals, disclosure management in the reporting of charity care, and managerial choices related to non-operating expenditures and asset dispositions.

How prevalent is disclosure management in the nonprofit sector? Some studies suggest it is widespread, while others downplay its significance. Certain factors are positively associated with financial disclosure management, or at least with the likelihood of financial disclosure management: small size, greater sensitivity of donations or managerial compensation to the program ratio, and financial distress (higher debt levels). What are the consequences of such disclosure management? Some studies suggest that users are misled and resources misallocated, while others conclude that many users are sophisticated enough to undo the managed numbers. One point that is frequently overlooked is the fact that different users have access to different financial information. IRS Form 990 is the primary public disclosure, and because of its ready availability is the most likely source of information for small donors. However, some evidence suggests that small donors do not utilize financial information in making donation decisions, so little harm is done if Form 990 numbers are manipulated. Major donors, on the other hand, are likely to be more sophisticated and to be in a position to request and receive audited financial statements. If the audited statements have been affected by financial disclosure management, the potential for misallocation of resources is much greater. Unfortunately, most financial disclosure management research uses Form 990 data. Conclusions about the frequency, severity, and negative consequences of disclosure management are possibly overstated by those studies.

What can be done to prevent or at least discourage disclosure management? Research has revealed a number of factors that appear to mitigate financial disclosure management, most of them obvious: larger size, older age, use of accrual accounting or professional outside accountants, undergoing an audit, use of professional management, greater external monitoring and tighter regulation (for example, enactment of SOP 98-2). Better accounting standards, particularly in the area of appropriate cost allocations, and more regulation aimed at improving reporting quality would appear to go a long way toward minimizing the opportunities for disclosure management. Rather than waiting for states or the IRS to enact stricter reporting requirements, donors have the power to take a governance role 
and demand greater nonprofit accountability. One way to accomplish this is to impose restrictions on donations and require the organization to report regarding the use of the funds.

There are a number of limitations inherent in the research reviewed in this paper, many of which have already been discussed. Care must be taken when drawing conclusions from what one thinks the research has revealed; there is potentially a great deal of endogeneity or simultaneity among the variables entering the various equations. For example, it has been established that donations are positively correlated with program ratios. However, is this because donors consider the program ratio before deciding to whom or how much to donate, or is it because nonprofits with superior management and fundraising teams are able to pull in more money and spend it more efficiently? Among the papers reviewed, the reader will have noticed that some researchers use donations as the dependent variable and interpret a positive coefficient on the program ratio as evidence that donors use it in making donation decisions, while others use the program ratio as the dependent variable and interpret the positive coefficient on donations as an indication that reliance on donations creates incentives to inflate the program ratio. It is not certain which is the direction of causation, or if both variables are jointly (or separately) determined by other factors.

Individually and collectively, the results of these studies have important implications for accounting academics and practitioners as well as for the public. Researchers must deal with the possibility that reported numbers may not be accurate representations and should consider the likelihood of accounting manipulation and any bias it might introduce into a data set. Auditors may need to develop more sophisticated guidelines for judging the reasonableness of nonprofit cost classifications and allocations. Donors and potential donors must be wary of financial reports that appear too good to be true (zero fundraising costs) or that include allocations of joint costs to programs. Policymakers must consider the potential misallocation of resources that results when donors are misled by inflated efficiency ratios. State and federal regulators should consider imposing requirements that will improve the quality of nonprofit financial reporting (providing the benefits exceed the costs). Donors should consider the role they can play in nonprofit governance and accountability.

This review of research to date has perhaps raised more questions than it has answered. The topic has not been exhausted, and the research is far from mature. A number of areas merit further inquiry. First and foremost, perhaps, is the issue of methodology. Data and model specification problems raise questions about the validity or generalizability of many of the studies. Can better models be designed to predict nonprofit revenues/expenses in order to estimate financial disclosure management? Future research will also be more compelling if it is based on the same data that decision-makers are most likely to use. Some research needs to be taken to the next level. For example, there is ample evidence that nonprofits likely manage the expenses reported on their UBIT returns; however, research to date cannot establish whether this constitutes illegal tax evasion, accounting incompetency, or smart tax planning. Future research might examine how the program ratio interacts with changes in unrelated business revenue or whether UBIT misreporting is associated with the program ratio or with the proportion of revenue received through donations.

Additional areas also remain to be examined. The issue of disclosure management related to revenues is virtually unexplored: restricted versus unrestricted, net revenues versus gross revenues, timing issues, etc. Another angle would be differences in motivation for disclosure management based on differences in sources of revenue: donations versus program services, for example, or public support versus grants from foundations or feeder agencies. There has been little research regarding potential disclosure management relating to asset or liability recognition and valuation. What about disclosure management related to the use of debt? It would be interesting to compare Leone and Van Horn's (2005) study using nonprofit hospitals that issue public debt to a group of nonprofit hospitals without any public debt to see how the presence/absence of public debt affects the incentives and opportunities for disclosure management.

While the donations market motivation for disclosure management has been heavily researched, much less work has been done regarding the incentives to misreport amounts that might affect managerial compensation or the cost of debt. Studies regarding misreporting to avoid political costs have focused on tax and regulator consequences. Have other potential motivations for financial disclosure management been overlooked? One area that might prove interesting is the impact of 
financial reporting on the nonprofit's public image or reputation as portrayed in the media. Nonprofit managers are conscious of the fact that having financial reports available to the donating public means that information regarding executive compensation, fundraising costs, and other potentially embarrassing items is open to media scrutiny. In the age of WikiLeaks, Twitter, and viral videos, is it possible that nonprofits manage financial information to avoid negative media attention?

On a more theoretical level, perhaps it would be enlightening to compare disclosure management across different types of nonprofits. Gordon and Khumawala (1999) suggest that the demand for and use of financial statement information by donors varies among types of nonprofits and donors. They end their paper with a series of research proposals positing that the demand for financial reporting is greatest in situations where the donor (1) has little contact with the ultimate beneficiaries of the gift, (2) has little involvement with the recipient organization, (3) receives little tangible or intangible reward for giving, (4) is choosing from among competing organizations, or (5) makes large and frequent donations. Non-charitable nonprofits such as social clubs, homeowners associations, and trade and professional associations are representative of situations where the donors or members are likely to be more involved with the organization or to receive tangible goods and services from the organization, and thus would have less need for financial information (Keating \& Frumkin, 2003). ${ }^{24}$ Future research could examine whether financial disclosure management is less prevalent among exempt membership organizations or in other situations where there is less stakeholder interest in financial statements and thus less incentive to manipulate financial statement amounts. Replicating a study on a population that lacks the same motivations for disclosure management can serve to validate (or not) the original study.

Last, there are questions relating to audits and other means of reducing disclosure management and improving reporting quality. What kind of guidelines, if any, do auditors use in judging the reasonableness of nonprofit cost classifications and joint cost allocations? How do auditors apply the three criteria of SOP 98-2 in testing the appropriateness of joint cost allocations? Can better costallocation guidelines be developed, and would that curtail disclosure management related to cost allocations? What specific governance mechanisms are most effective at improving reporting quality? Can SOX-type provisions be applied to nonprofits? The IRS has recently revised Form 990 and is now collecting more variables, including a section on governance, management, and disclosure. As more data becomes available, more sophisticated analyses become possible. Many of these questions can also be addressed through experimental studies. Financial disclosure management in the nonprofit sector remains a fruitful area of inquiry for accounting researchers.

\section{Acknowledgements}

We appreciate the helpful comments of the editor, anonymous reviewer, Dana Forgione, Bambi Hora, Linda Parsons, Andrea Roberts, and conference participants at the 2011 Government and Nonprofit Section of the American Accounting Association Midyear Conference, the 2011 Southeast Region of the American Accounting Association Meeting, and the 2011 American Accounting Association Annual Meeting.

\section{References}

Aggarwal, R., Evans, E., \& Nanda, D. (2012). Nonprofit boards: Size, performance and managerial incentives. Journal of Accounting and Economics, 53, 466-487.

American Institute of Certified Public Accountants (AICPA). (1987). Accounting for joint costs of informational materials and activities of not-for-profit organizations that include a fund-raising appeal. Statement of position no. 87-2. New York, NY: AICPA.

American Institute of Certified Public Accountants (AICPA). (1998). Accounting for costs of activities of not-for-profit organizations and state and local governmental entities that include fund-raising. Statement of position no. 98-2. New York, NY: AICPA.

Baber, W., Roberts, A., \& Visvanathan, G. (2001). Charitable organizations' strategies and program spending ratios. Accounting Horizons, 15(4), 329-343.

Baber, W., Daniel, P., \& Roberts, A. (2002). Compensation to managers of charitable organizations: An empirical study of the role of accounting measures of program activities. Accounting Review, 77(3), 679-693.

\footnotetext{
${ }^{24}$ Hofmann (2002) surveys exempt membership organizations regarding their financial reporting practices; 75 percent (95 percent) of survey respondents indicate that they receive fewer than five requests per year for financial statements (Form 990 tax returns).
} 
Ballantine, J., Forker, J., \& Greenwood, M. (2007). Earnings management in English NHS hospital trusts. Financial Accountability \& Management, 23(4), 421-440.

Barrett, W. (1999). Look before you give. Forbes, 164(December (27)), 208-216.

Beaver, W., McNichols, M., \& Nelson, K. (2003). Management of the loss reserve accrual and the distribution of earnings in the property-casualty insurance industry. Journal of Accounting and Economics, 35(3), 347-376.

Beyer, A., Cohen, D., Lys, T., \& Walther, B. (2010). The financial reporting environment: Review of the recent literature. Journal of Accounting and Economics, 50(2/3), 296-343.

Bhattacharya, R., \& Tinkelman, D. (2009). How tough are Better Business Bureau/Wise Giving Alliance financial standards? Nonprofit and Voluntary Sector Quarterly, 38(3), 467-489.

Brickley, J., \& Van Horn, R. (2002). Managerial incentives in nonprofit organizations: Evidence from hospitals. Journal of Law and Economics, 45(1), 227-249.

Brooks, A. (2008). A nation of givers. The American2(2) Accessed at http://www.american.com/archive/2008/march-april-magazinecontents/.

Buchheit, S., \& Parsons, L. (2006). An experimental investigation of accounting information's influence on the individual giving process. Journal of Accounting and Public Policy, 25(6), 666-686.

Burgstahler, D., \& Dichev, I. (1997). Earnings management to avoid earnings decreases and losses. Journal of Accounting and Economics, 24(1), 99-126.

Callen, J. (1994). Money donations, volunteering and organization efficiency. Journal of Productivity Analysis, 5(October), 215-228.

Capin, G., \& Tanenbaum, J. (1998). How to report a joint activity. Journal of Accountancy, 186(2), 37-44.

Chase, B., \& Coffman, E. (1994). Choice of accounting method by not-for-profit institutions: Accounting for investments by colleges and universities. Journal of Accounting and Economics, 18(2), 233-243.

Christensen, A., \& Mohr, R. (1995). Testing a positive theory of museum accounting practices. Financial Accountability and Management, 11(4), 317-335.

Cordes, J., \& Weisbrod, B. (1998). Differential taxation of nonprofits and the commercialization of nonprofit revenues. Journal of Policy Analysis and Management, 17(2), 195-214.

Core, J., Guay, W., \& Verdi, R. (2006). Agency problems of excess endowment holdings in not-for-profit firms. Journal of Accounting and Economics, 41, 307-333.

Dechow, P., \& Dichev, I. (2002). The quality of accruals and earnings: The role of accrual estimation errors. Accounting Review, 77(Suppl.), 35-59.

Dechow, P., Richardson, S., \& Tuna, I. (2003). Why are earnings kinky? An examination of the earnings management explanation. Review of Accounting Studies, 8(2/3), 355-384.

Dechow, P., Ge, W., \& Schrand, C. (2010). Understanding earnings quality: A review of the proxies, their determinants and their consequences. Journal of Accounting and Economics, 50(2/3), 344-401.

DeFond, M., \& Jiambalvo, J. (1994). Debt covenant violation and manipulation of accruals. Journal of Accounting and Economics, 17(1/ 2), 145-176.

Desai, M., \& Yetman, R. (2005). Constraining managers without owners: Governance of the not-for-profit enterprise. NBER working paper serieshttp://www.nber.org/papers/w11140.

Dimsdale, J. (2009). Financial issues cut into Red Cross. American public media program.

Durtschi, C., \& Easton, P. (2005). Earning management? The shapes of frequency distributions of earnings metrics are not evidence ipso facto. Journal of Accounting Research, 43(4), 557-592.

Eldenburg, L., \& Soderstrom, N. (1996). Accounting system management by hospitals operating in a changing regulatory environment. Accounting Review, 71(1), 23-42.

Eldenburg, L., \& Kallapur, S. (1997). Changes in hospital service mix and cost allocations in response to changes in Medicare reimbursement schemes. Journal of Accounting and Economics, 23(1), 31-51.

Eldenburg, L., \& Vines, C. (2004). Nonprofit classification decisions in response to a change in accounting rules. Journal of Accounting and Public Policy, 23(1), 1-22.

Eldenburg, L., Gunny, K., Hee, K., \& Soderstrom, N. (2011). Earnings management using real activities: Evidence from nonprofit hospitals. Accounting Review, 86(5), 1605-1630.

Fama, E., \& Jensen, M. (1983a). Separation of ownership and control. Journal of Law and Economics, 26(2), 301-325.

Fama, E., \& Jensen, M. (1983b). Agency problems and residual claims. Journal of Law and Economics, 26(2), 327-349.

Financial Accounting Standards Board (FASB). (1993). Financial statements of not-for-profit organizations. Statement of financial accounting standards no. 117. Norwalk, CT: FASB.

Financial Accounting Standards Board (FASB). (2009). Accounting standards codification. Norwalk, CT: FASB.

Fischer, M., Gordon, T., \& Kraut, M. (2002). An examination of differences between financial information provided in IRS Forms 990 and audited financial statements of U.S. private colleges and universities. Academy of Accounting and Financial Studies Journal, 6(1), 88-105.

Froelich, K., Knoepfle, T., \& Pollak, T. (2000). Financial measures in nonprofit organization research: Comparing IRS 990 return and audited financial statement data. Nonprofit and Voluntary Sector Quarterly, 29(2), 232-254.

Gordon, T., \& Khumawala, S. (1999). The demand for not-for-profit financial statements: A model of individual giving. Journal of Accounting Literature, 18(1), 31-56.

Gordon, T., Greenlee, J., \& Nitterhouse, D. (1999). Tax-exempt organization financial data: Availability and limitations. Accounting Horizons, 13(2), 113-128.

Gordon, T., Knock, C., \& Neely, D. (2009). The role of rating agencies in the market for charitable contributions: An empirical test. Journal of Accounting and Public Policy, 28(6), 469-484.

Greene, W. (1997). Econometric analysis. Upper Saddle River, NJ: Prentice Hall.

Greenlee, J., \& Brown, K. (1999). The impact of accounting information on contributions to charitable organizations. Research in Accounting Regulation, 13(September), 111-125.

Greenlee, J., \& Trussel, J. (2000). Predicting the financial vulnerability of charitable organizations. Nonprofit Management and Leadership, 11(2), 199-210.

Grein, B., \& Tate, S. (2011). Monitoring by auditors: The case of public housing authorities. Accounting Review, 86(4), 1289-1319. 
Guenther, D. (1994). Earnings management in response to corporate tax rate changes: Evidence from the 1986 Tax Reform Act. Accounting Review, 69(1), 230-243.

Guidry, F., Leone, A., \& Rock, S. (1999). Earnings-based bonus plans and earnings management by business-unit managers. Journal of Accounting and Economics, 26(1-3), 113-142.

Han, J., \& Wang, S. (1998). Political costs and earnings management of oil companies during the 1990 Persian Gulf Crisis. Accounting Review, 73(1), 103-117.

Healy, P., \& Wahlen, J. (1999). A review of the earnings management literature and its implications for standard setting. Accounting Horizons, 13(4), 365-383.

Hoerger, T. (1991). "Profit" variability in for-profit and not-for-profit hospitals. Journal of Health Economics, 10(3), 259-289.

Hofmann, M. (2002). The unrelated business income tax and cost shifting by certain exempt membership organizations. Arizona State University (Ph.D. dissertation).

Hofmann, M. (2007). Tax-motivated expense shifting by tax-exempt associations. Journal of the American Taxation Association, 29(1), 43-60.

Jegers, M. (2010). The effect of board-manager agency conflicts on non-profit organisations' earnings and cost allocation manipulations. Accounting and Business Research, 40(5), 407-419.

Jones, J. (1991). Earnings management during import relief investigations. Journal of Accounting Research, 29(2), 193-228.

Jones, C., \& Roberts, A. (2006). Management of financial information in charitable organizations: The case of joint-cost allocations. Accounting Review, 81(1), 159-178.

Kane, N. (2007). Tax-exempt hospitals: What is their charitable responsibility and how should it be defined and reported? Saint Louis University Law Journal, 51(Winter), 459-474.

Kasznik, R. (1999). On the association between voluntary disclosure and earnings management. Journal of Accounting Research, 37(1), 57-81.

Keating, E., \& Frumkin, P. (2003). Reengineering nonprofit financial accountability: Toward a more reliable foundation for regulation. Public Administration Review, 63(1), 3-15.

Keating, E., Parsons, L., \& Roberts, A. (2008). Misreporting fundraising: How do nonprofit organizations account for telemarketing campaigns? Accounting Review, 83(2), 417-446.

Khumawala, S., \& Gordon, T. (1997). Bridging the credibility of GAAP: Individual donors and the new accounting standards for nonprofit organizations. Accounting Horizons, 11(3), 45-68.

Khumawala, S., Parsons, L., \& Gordon, T. (2005). TRACKS: Assessing the quality of not-for-profit efficiency rations: Do donors use joint cost allocation disclosures? Journal of Accounting, Auditing E Finance, 20(3), 287-309.

Kitching, K. (2009). Audit value and charitable organizations. Journal of Accounting and Public Policy, 28(6), 510-524

Krishnan, R., Yetman, M., \& Yetman, R. (2006). Expense misreporting in nonprofit organizations. Accounting Review, 81(2), 399-420.

Krishnan, R., \& Yetman, M. (2011). Institutional drivers of reporting decisions in nonprofit hospitals. Journal of Accounting Research, 49(4), 1001-1039.

Leone, A., \& Van Horn, R. (2005). How do nonprofit hospitals manage earnings? Journal of Health Economics, 24(4), 815-837.

Lopez, T., Regier, P., \& Lee, T. (1998). Identifying tax-induced earnings management around TRA 86 as a function of prior taxaggressive behavior. Journal of the American Taxation Association, 20(2), 37-56.

Marudas, N. (2004). Effects of nonprofit organization wealth and efficiency on private donations to large nonprofit organizations. Research in Governmental and Nonprofit Accounting, 11, 71-91.

McNichols, M., \& Wilson, G. (1988). Evidence of earnings management from the provision for bad debts. Journal of Accounting Research, 26(Suppl.), 1-31.

McNichols, M. (2000). Research design issues in earnings management studies. Journal of Accounting and Public Policy, 19(4/5), 313345.

McNichols, M. (2002). Discussion of the quality of accruals and earnings: The role of accruals estimation errors. Accounting Review, 77(Suppl.), 61-69.

Mensah, Y., Considine, J., \& Oakes, L. (1994). Statutory insolvency regulations and earnings management in the prepaid health-care industry. Accounting Review, 69(1), 70-95.

Missouri Foundation for Health. (2005). Issue overview: Hospital charity care in the United States. Summer 2005 Retrieved from http:// www.mffh.org/mm/files/HospitalChairtyCareIssueBrief.pdf.

Okten, C., \& Weisbrod, B. (2000). Determinants of donations in private nonprofit markets. Journal of Public Economics, 75(2), 255-272.

Omer, T., \& Yetman, R. (2003). Near zero taxable income reporting by nonprofit organizations. Journal of the American Taxation Association, 25(2), 19-24.

Omer, T., \& Yetman, R. (2007). Tax misreporting and avoidance by nonprofit organizations. Journal of the American Taxation Association, 29(1), 61-86.

Parsons, L. (2003). Is accounting information from nonprofit organizations useful to donors? A review of charitable giving and valuerelevance. Journal of Accounting Literature, 22, 104-129.

Parsons, L. (2007). The impact of financial information and voluntary disclosures on contributions to not-for-profit organizations Behavioral Research in Accounting, 19(1), 179-196.

Parsons, L., Pryor, C., \& Roberts, A. (2012). The use of real ratio management or accounting discretion to manage efficiency ratios: Evidence from nonprofit managers. SSRN working paper series (06)http://0-search.proquest.com.wncln.wncln.org/docview/ 1323942620 ?accountid=8337.

Peat, M. (1985). Principles \& presentation: Higher education. New York, NY: Peat Marwick Mitchell \& Company.

Petrovits, C. (2006). Corporate-sponsored foundations and earnings management. Journal of Accounting and Economics, 41(3), 335362.

Phillips, J., Pincus, M., Rego, S., \& Wan, H. (2004). Decomposing changes in deferred tax assets and liabilities to isolate earnings management activities. Journal of the American Taxation Association, 26(Suppl.), 43-66.

Posnett, J., \& Sandler, T. (1989). Demand for charity donations in private non-profit markets: The case of the UK. Journal of Public Economics, 40(2), 187-200.

Press, E., \& Weintrop, J. (1990). Accounting-based constraints in public and private debt agreements: Their association with leverage and impact on accounting choice. Journal of Accounting E Economics, 12(1-3), 65. 
Roychowdhury, S. (2006). Earnings management through real activities manipulation. Journal of Accounting and Economics, 42(3), 335-370.

Rucker, P. (2007). United way fundraising rises after scandal-induced plunge. Washington Post, November: B-3.

Sansing, R. (1998). The unrelated business income tax, cost allocation, and productive efficiency. National Tax Journal, 51(2), $291-302$.

Sansing, R., \& Yetman, R. (2006). Governing private foundations using the tax law. Journal of Accounting and Economics, 41, 363-384.

Schmidt, A. (2007). Discussion of tax misreporting and avoidance by nonprofit organizations. Journal of the American Taxation Association, 29(1), 87-92.

Simon, J., Dale, H., \& Chisolm, L. (2007). The federal tax treatment of charitable organizations. In W. Powell (Ed.), The nonprofit sector: A research handbook (pp. 267-306). New Haven: Yale University Press.

Smith, M. (1993). Best charities in America. Money, 22(12), 128-132.

Steinberg, R. (1986). The revealed objective functions of nonprofit firms. RAND Journal of Economics, 17(4), 508-526.

Stolowy, H., \& Breton, G. (2004). Accounts manipulation: A literature review and proposed conceptual framework. Review of Accounting and Finance, 3(1), 5-66.

Teoh, S., Welch, I., \& Wong, T. (1998). Earnings management and the underperformance of seasoned equity offerings. Journal of Financial Economics, 50(1), 63-99.

Thornton, J., \& Belski, W. (2010). Financial reporting quality and price competition among nonprofit firms. Applied Economics, 42(21), 2699-2713.

Tinkelman, D. (1998). Differences in sensitivity of financial statement users to joint cost allocations: The case of nonprofit organizations. Journal of Accounting, Auditing E Finance, 13(4), 377-393.

Tinkelman, D. (1999). Factors affecting the relation between donations to nonprofit organizations and an efficiency ratio. Research in Governmental and Nonprofit Accounting, 10, 135-161.

Tinkelman, D. (2009). Unintended consequences of expense ratio guidelines: The Avon breast cancer walks. Journal of Accounting and Public Policy, 28(6), 485-494.

Tishlias, D. (1992). Reasonable joint cost allocations in nonprofits. Journal of Accountancy, 174(5), 64-68.

Trueman, B., \& Titman, S. (1988). An explanation for accounting income smoothing: Discussion. Journal of Accounting Research, 26(Suppl.), 127-139.

Trussel, J. (2003). Assessing potential accounting manipulation: The financial characteristics of charitable organizations with higher than expected program-spending ratios. Nonprofit and Voluntary Sector Quarterly, 32(4), 616-634.

Tuckman, H., \& Chang, C. (1991). A methodology for measuring the financial vulnerability of charitable nonprofit organizations. Nonprofit and Voluntary Sector Quarterly, 20(4), 445-460.

United States General Accounting Office (GAO). (2002). Report to the Chairman and Ranking Minority Member, Committee on Finance, U.S. Senate. GAO-02-526. Washington, DC: Government Printing Office.

United States Office of Management and Budget (OMB). (2007). Audits of state and local governments, circular no. A-133. Washington, DC: Government Printing Office.

Vansant, B. (2011). The effect of regulatory pressures on earnings management behavior of nonprofit hospitals. SSRN working paper series (07)http://0-search.proquest.com.wncln.wncln.org/docview/749421129?accountid=8337.

Watts, R., \& Zimmerman, J. (1986). Positive accounting theory. Englewood Cliffs, New Jersey: Prentice Hall Inc.

Weisbrod, B., \& Dominguez, N. (1986). Demand for collective goods in private nonprofit markets: Can fundraising expenditures help overcome free-rider behavior? Journal of Public Economics, 30(1), 83-95.

Wing, K., Roeger, K., \& Pollak, T. (2010). The nonprofit sector in brief: Public charities, giving, and volunteering, 2010. Washington, DC: National Center for Charitable Statistics, Urban Institute Available at: http://www.urban.org/UploadedPDF/412209-nonprofpublic-charities.pdf.

Yetman, R. (2001). Tax-motivated expense allocations by nonprofit organizations. Accounting Review, 76(3), 297-311.

Yetman, M., Yetman, R., \& Badertscher, B. (2009). Calibrating the reliability of publicly available nonprofit taxable activity disclosures: Comparing IRS 990 and IRS 990-T data. Nonprofit and Voluntary Sector Quarterly, 38(1), 95-116.

Yetman, M., \& Yetman, R. (2011). The effects of governance on the accuracy of charitable expense reported by nonprofit organizations. Contemporary Accounting Research http://dx.doi.org/10.1111/j.1911-3846.2011.01121.x (in press).

Yetman, M., \& Yetman, R. (2013). Do donors discount low-quality accounting information? Accounting Review, 88(3), 1041-1067.

Yoder, T., Addy, N., \& McAllister, B. (2011). Tax-motivated increases in qualifying distributions by private foundations. Journal of the American Taxation Association, 33(1), 79-108. 